ARTIGOS 


\title{
AS NOTAS DE RODAPÉ DE CAPISTRANO DE ABREU: AS EDIÇÕES DA COLEÇÃO MATERIAIS E ACHEGAS PARA A HISTÓRIA E GEOGRAFIA DO BRASIL $(1886-1887)^{*}$
}

\author{
Pedro Afonso Cristovão dos Santos \\ Mestre em História Social e doutorando no Programa de Pós-Graduação \\ em História Social da Faculdade de Filosofia, Letras e Ciências Humanas \\ da Universidade de São Paulo.
}

\section{Resumo}

Este artigo estuda as edições de documentos históricos a cargo do historiador João Capistrano de Abreu (1853-1927) na Coleção Materiais e achegas para a história e geografia do Brasil (1886-1887). No estudo, examinamos as notas de rodapé de Capistrano, assinalando a forma como o autor prepara, por meio delas, os textos editados para serem lidos enquanto fontes.

\section{Palavras-chave}

Capistrano de Abreu $\bullet$ metodologia da história $\bullet$ fontes.

\section{Correspondência}

Departamento de História - FFLCH/USP

Av. Prof. Lineu Prestes, 338

05508-000 - Cidade Universitária - São Paulo - SP

E-mail: pedro.afonso.santos@usp.br

* Este artigo procede de uma re-elaboração de parte do segundo capítulo de nossa dissertação de Mestrado, História erudita e popular: edição de documentos históricos na obra de Capistrano de Abreu. FFLCH/USP, 2009. Agradeço ao CNPq pelo apoio financeiro concedido à pesquisa. 


\title{
THE FOOTNOTES OF CAPISTRANO DE ABREU: THE EDITIONS OF THE MATERIAIS E ACHEGAS PARA A HISTÓRIA E GEOGRAFIA DO BRASIL SERIES (1886-1887)
}

\author{
Pedro Afonso Cristovão dos Santos \\ Master's degree in Social History, Program of Post-Graduation in Social \\ History of the Faculdade de Filosofia, Letras e Ciências Humanas of the Universidade de São Paulo, \\ and currently candidate for a doctorate in the same Program of Post-Graduation.
}

\section{Abstract}

This article studies the editions of historical documents by João Capistrano de Abreu (1853-1927), in the series Materiais e achegas para a história e geografia do Brasil, (1886-1887). The study focuses on the footnotes written by Capistrano, pointing the way in which the author prepared the documents to be read as sources.

\section{Keywords}

Capistrano de Abreu $\bullet$ methodology of history $\bullet$ sources.

\section{Contact}

Departamento de História - FFLCH/USP

Av. Prof. Lineu Prestes, 338

05508-000 - Cidade Universitária - São Paulo - SP

E-mail: pedro.afonso.santos@usp.br

This article is based on part of the second chapter of our Master's dissertation, intitled Historia erudita e popular: edição de documentos históricos na obra de Capistrano de Abreu. FFLCH-USP, 2009. The author thanks the $\mathrm{CNPq}$ for the financing of the research. 


\section{Apresentação}

A obra de João Capistrano de Abreu (1853-1927) já mereceu muitos estudos. Em vários deles, foi destacada sua erudição e crítica documental como traços significativos não apenas de sua produção individual, mas marcantes também na própria história da historiografia brasileira. Recentemente, alguns estudos têm se debruçado especificamente sobre estas questões, destacando seu trabalho de anotação de textos históricos ou historiográficos. ${ }^{1}$ Neste artigo, procuraremos contribuir para a compreensão de sua concepção e prática da erudição histórica por meio do estudo de seu trabalho de anotação de textos na Coleção Materiais e achegas para a história e geografia do Brasil, que Capistrano ajudou a editar nos anos 1880.

\section{A Coleção Materiais e achegas para a história e geografia do Brasil(1886-1887)}

Esta coleção foi o principal meio planejado por Capistrano de Abreu e dois de seus colegas de trabalho na Biblioteca Nacional do Rio de Janeiro, Alfredo do Vale Cabral e José Alexandre Teixeira de Melo, para editar fontes da história do Brasil (como diz o título da série). Havia outras possibilidades: a própria Biblioteca Nacional possuía, desde 1876, um periódico, os Anais (iniciativa do então diretor Ramiz Galvão), que publicava documentos históricos de seu acervo. Capistrano havia editado, em 1881, Do princípio e origem dos índios do Brasil e de seus costumes, adoração e cerimônias, obra do final do século XVI, do jesuíta português Fernão Cardim, pela tipografia da Gazeta de Notícias, onde trabalhava, em edição custeada pelo publisher da Gazeta, Ferreira de Araújo (a edição fora oferecida à Biblioteca Nacional, para constar da Exposição de História e Geografia do Brasil, de 1881, mas não ficou pronta a tempo). Outros periódicos também poderiam servir ao mesmo propósito, naquele momento, como a Revista Mensal da Seção da Sociedade de Geografia de Lisboa no Brasil, onde Capistrano publicou outro escrito de Cardim, "Do clima do Brasil e de algumas coisas notáveis que se acham assim na terra como no mar”, em 1885, além de

\footnotetext{
Por exemplo, GONTIJO, Rebeca. O velho vaqueano: Capistrano de Abreu, da historiografia ao historiador. Tese de Doutorado, UFF, Niterói, 2006; OLIVEIRA, Maria da Glória de. Crítica, método e escrita da história em João Capistrano de Abreu (1853-1927). Dissertação de Mestrado, Programa de Pós-Graduação em História da Universidade Federal do Rio Grande do Sul. Porto Alegre, 2006; AMED, Fernando José. Atravessar o oceano para verificar uma vírgula: Francisco Adolfo de Varnhagen (1816-1878) lido por João Capistrano de Abreu (1853-1927). Tese de Doutorado, Programa de Pós-Graduação em História Social do Departamento de História da FFLCHUSP, São Paulo, 2007. Na nossa dissertação de Mestrado, citada na nota 1, fazemos um balanço da historiografia sobre Capistrano, atentando para as análises sobre seu método e crítica documental.
} 
outros documentos. ${ }^{2}$ Vale Cabral e Teixeira de Melo foram eles mesmos editores de um periódico de vida efêmera, entre 1883 e 1884, a Gazeta Literária, que possuía uma seção, a Gazeta Colonial, que abria espaço para a publicação de textos antigos - Capistrano editou alguns ali. ${ }^{3}$ Talvez o maior índice do trabalho dos funcionários da Biblioteca Nacional com documentos históricos, naqueles anos, tenha sido, entretanto, a Exposição de História e Geografia do Brasil, de 1881, à qual devemos acrescentar os nomes de João Ribeiro e Menezes Brun. Para Capistrano, seu grande resultado fora o monumental Catálogo produzido para a exposição, como se recordaria na nota preliminar da edição de 1918 da História do Brasil de frei Vicente do Salvador. ${ }^{4}$ Capistrano, Vale Cabral e Teixeira de Melo vinham, assim, num intenso esforço de localização das fontes para a história e geografia do Brasil, com esforço correlato de disponibilizá-las, ou, ao menos, indicar os meios de acesso a elas. Todo esse trabalho, podemos talvez dizê-lo, já estava trazendo-lhes fama como conhecedores dos "papéis velhos" e livros antigos da história do Brasil. Ao colaborar, em 1881, com o editor chefe da citada Revista Mensal da Seção da Sociedade de Geografia de Lisboa no Brasil, Fernando Mendes de Almeida, na identificação de um texto encontrado entre os papéis do recém-falecido pai de Fernando, Cândido Mendes de Almeida, que seria por Capistrano identificado como escrito de Fernão Cardim, do século XVI, Capistrano foi apresentado pelo editor da revista, a seus leitores, como o "distinto bibliógrafo e bibliófilo o sr. João Capistrano de Abreu". 5

2 Documentos transcritos no artigo Robério Dias e as Minas de Prata, segundo novos documentos. Revista Mensal da Seção da Sociedade de Geografia de Lisboa no Brasil, set. - out. de 1885 e Parecer e tratado feito sobre os excessivos impostos que caíram sobre as lavouras do Brasil, arruinando o comércio dele, - feito por João Peixoto Viegas, enviado ao senhor Marquês das Minas, Conselheiro de Sua Majestade e então Governador Geral da Cidade da Bahia. In: Revista Mensal da Seção da Sociedade de Geografia de Lisboa no Brasil, $2^{\mathrm{a}}$ série, $\mathrm{n}^{\circ}$ 4, primeiro trimestre de 1886.

3 A bandeira do Anhanguera a Goiás em 1722, segundo José Peixoto da Silva Braga. In: Gazeta Literária, ano $\mathrm{I}, \mathrm{n}^{\circ} 3,1^{\circ}$ de novembro de 1883 e ano $\mathrm{I}, \mathrm{n}^{\circ} 5,1^{\circ}$ de dezembro de 1883 , e A bandeira de Francisco de Melo Palheta ao Madeira em 1722-23, segundo um dos seus companheiros. In: Gazeta Literária, ano I (sic), n 20, 24 de novembro de 1884.

4 SALVADOR, frei Vicente do. História do Brasil. São Paulo: Edições Melhoramentos, 1975, p. 29. Segundo José Honório Rodrigues, o Catálogo era "a maior bibliografia histórica publicada sobre um país no mundo. Nem as bibliografias do mundo europeu, nem as norte-americanas se comparavam, na época, ao Catálogo da Exposição de História do Brasil publicado em 1881”. (Catálogo da Exposição de História do Brasil. Introdução de José Honório Rodrigues; apresentação de B. F. Ramiz Galvão. Ed. fac-similada. Brasília, Distrito Federal: Editora Universidade de Brasília, c. 1981, p. VIII-IX). Sobre o Catálogo e a exposição, baseamo-nos também em AMED, Fernando. As cartas de Capistrano de Abreu: sociabilidade e vida literária na belle époque carioca. São Paulo: Alameda, 2006, p. 84-85.

5 Apud CARMO, José Arimateia Pinto. Bibliografia de Capistrano de Abreu. Rio de Janeiro: Imprensa Nacional, 1942, p. 79. 
No entanto, nenhum dos meios até então conseguidos para publicação dos textos históricos provou-se regular ou adequado aos propósitos imaginados pelo trio (principalmente Capistrano e Vale Cabral). Sua intenção parecia ser produzir edições críticas, o que aparentemente não se adequava ao suporte periódico, em função da necessidade de notas, introduções, glossários etc.; e, por outro lado, procuravam realizar edições que "vulgarizassem", "popularizassem", aqueles textos, como eles mesmos afirmavam. Para isto, além do aparato crítico voltado para melhor compreensão do que se lia, far-se-iam opções editoriais que pareciam não ter lugar em periódicos como o da Biblioteca Nacional, tal qual a modernização da escrita, atualizando o português antigo (nos Anais da Biblioteca Nacional, como na Revista do Instituto Histórico e Geográfico Brasileiro, talvez a principal publicação brasileira de então para este tipo de texto, ${ }^{6}$ os textos de época vinham, normalmente, na grafia original). Portanto, Capistrano, Vale Cabral e Teixeira de Melo só realizariam o trabalho que julgavam necessário, de produzir edições críticas, mas, ao mesmo tempo, de "vulgarização", se encontrassem um meio que, além de seguro, capaz de fornecer publicações regulares, possibilitasse a concretização das opções editoriais que tinham em mente.

Capistrano imaginara inicialmente uma associação particular em que os próprios membros financiassem as publicações. ${ }^{7} \mathrm{~A}$ ideia malogrou e ocorreu-lhe, então, valer-se de recurso que a Biblioteca Nacional possuía desde a exposição de 1881: uma permissão do governo para imprimir documentos e livros raros da história do Brasil pela Tipografia Nacional, saindo os textos em seção do Diário Oficial e depois em volume. A permissão fora concedida pelo conselheiro José Antônio Saraiva a Ramiz Galvão, diretor da Biblioteca quando da exposição, após

\footnotetext{
${ }^{6}$ Capistrano chegaria a valer-se da Revista do IHGB para publicar documentos, mas esta nunca parece ter sido uma opção que lhe atraísse muito; em diversos momentos, Capistrano questionou a qualidade das edições de documento pelos membros do Instituto, chegando a afirmar, em artigo de 2 de setembro de 1881: "Parece incrível, mas é exato; quase não há no Instituto quem saiba fazer esta coisa tão simples - editar um livro". (ABREU, João Capistrano de. Ensaios e estudos: crítica e história. $4^{\mathrm{a}}$ série. Rio de Janeiro: Civilização Brasileira; Brasília: INL, 1976, p. 282). Quanto às opções editoriais nesse tipo de periódico, um exemplo pode ser uma das raras edições do próprio Capistrano ali: Do princípio e origem dos índios do Brasil e de seus costumes, adoração e cerimônias, de Fernão Cardim, que Capistrano editara em livro, em 1881, apareceu, por sua obra, na Revista do IHGB, LVII, part. $1^{\mathrm{a}}, 1^{\circ}$ e $2^{\circ}$ trimestres de 1894, p. 185-212. Veio à luz, porém, sem a introdução e as notas de Capistrano, além de ter a grafia original (em 1881, surgira com grafia atualizada), e sem um glossário de termos indígenas elaborado por Batista Caetano, também presente na edição de 1881 .

7 Chamar-se-ia Clube Taques, em homenagem a Pedro Taques Paes Leme, cf. as cartas a Lino de Assunção de 08/08/1885 e 02/04/1886. ABREU, João Capistrano de. Correspondência de Capistrano de Abreu, volume $3^{\mathrm{a}}$ edição organizada e prefaciada por José Honório Rodrigues. $2^{\mathrm{a}}$ edição. Rio de Janeiro: Civilização Brasileira; Brasília: INL, 1977, p. 322-324 e 326-328.
} 
a visita daquele a esta, e concretizada em ofício de 2 de janeiro de 1882 . Nunca foi usada, porém, nem mesmo após Vale Cabral e Teixeira de Melo receberem permissão específica, em 20 de novembro de 1883, para publicarem, pela Tipografia Nacional, documentos e manuscritos inéditos relativos à história do Brasil existentes na Biblioteca. Capistrano recuperou-a, afirmando tratar-se, ainda, de um momento propício à sua execução, por ter boas relações no governo. ${ }^{8}$

A menção a uma boa relação pessoal indica um aspecto da cultura intelectual brasileira da época que viria, em outro momento da história da Coleção Materiais e achegas, a funcionar contra seus editores. Isto quando o então diretor da Biblioteca Nacional, Saldanha da Gama (que sucedeu Ramiz Galvão), decidiu impor obstáculos ao trabalho do trio Capistrano - Vale Cabral - Teixeira de Melo, impedindo-os, principalmente, de usar o exemplar da Biblioteca Nacional da História do Brasil, de frei Vicente do Salvador, obtido na exposição de 1881, para publicação na Coleção Materiais. A solução foi recorrer àquele que deve ser sido, de fato, também um realizador da coleção que estudamos: o engenheiro português Tomás Lino de Assunção. ${ }^{9}$ A correspondência entre Capistrano e Lino

\footnotetext{
8 A principal reconstituição da história desta coleção, de que nos valemos para os parágrafos acima, está na introdução de José Honório Rodrigues ao volume 73 dos Anais da Biblioteca Nacional, 1954, edição em homenagem a Alfredo do Vale Cabral. Cf., para o relato de Capistrano, a carta de 02/04/1886 a Lino de Assunção citada na nota acima. Ali, Capistrano afirma ter "boas relações" com Silveira Caldeira, então subdiretor do Diário Oficial, e com "o Belisário, primo do Ministro" - que seria Francisco Belisário Soares de Sousa (1839-1889), ministro da Fazenda entre 1885 e 1888. (ABREU. Correspondência, vol. 3, op. cit., p. 326). Capistrano não menciona a pré-existente permissão para publicações da Biblioteca Nacional.

9 Em carta de 7 de abril de 1886 a Lino de Assunção, que já os auxiliava com cópias de documentos, em Portugal, Capistrano começa a falar dos problemas com Saldanha da Gama na Biblioteca Nacional. (ABREU. Correspondência de Capistrano de Abreu, volume 3, op. cit., p. 328-329). As cartas seguintes a Lino continuam relatando a tensão (em especial a de 16 de maio de 1886; Ibidem, p. 333), e, na carta de 4 de agosto de 1886 (Ibidem, p. 339-341), Capistrano relata a "fúria" de Saldanha da Gama com o sucesso da estratégia adotada, diante da adversidade, pelos editores da Coleção Materiais: com a cópia de exemplar da História de frei Vicente obtida por Lino, em Portugal, iniciaram a publicação da obra no Diário Oficial que, imediatamente, granjeou repercussão positiva, como relata Capistrano na mesma carta de 4 de agosto. A querela também é contada por Capistrano ao barão do Rio Branco, em carta de 25 de novembro de 1886. (ABREU, João Capistrano de. Correspondência de Capistrano de Abreu, volume 1 edição organizada e prefaciada por José Honório Rodrigues. $2^{\text {a }}$. edição. Rio de Janeiro: Civilização Brasileira; Brasília: INL, 1977, p. 102-104). A obra de frei Vicente, porém, viria a ser editada com apoio de Saldanha da Gama nos Anais da Biblioteca Nacional, volume XIII, em 1888, e, em 1889, como separata do mesmo volume. (SALVADOR, frei Vicente do. História do Brasil. Rio de Janeiro: Tip. Leuzinger \& Filhos, 1889). Na introdução a esta edição, Capistrano omitiu as disputas quando da edição da Coleção Materiais. Talvez com algum exagero, o biógrafo de Alfredo do Vale Cabral, Frederico Edelweiss, atribuiu a este episódio com Saldanha da Gama o início dos problemas de saúde que teria Cabral, que o levariam à aposentadoria precoce, em 1890, e, posteriormente, ao falecimento. (EDELWEISS, Frederico. Ensaios biográficos. Salvador: Universidade Federal da Bahia, Centro
} 
revela o quanto o segundo colaborou nas pesquisas para obtenção de cópias de documentos nos arquivos portugueses e, notavelmente, o conhecimento que $\mathrm{Ca}$ pistrano tinha do que se encontrava nos arquivos no Brasil, e do havia ou poderia haver nos da Europa, mesmo sem nunca ter visitado os últimos. Servindo-se de citações encontradas nas obras de história, ou dos catálogos e obras bibliográficas da época, Capistrano pôde arriscar o paradeiro de vários papéis antigos. ${ }^{10}$

Valendo-se da permissão governamental, por conseguinte, puderam os três funcionários da Biblioteca Nacional, associados a Silveira Caldeira, do Diário Oficial, dar início ao empreendimento. Como constava do ofício original, os textos saíam primeiro no Diário, depois em volume, a impressão dependendo do ritmo e quantidade de papéis do governo que tinham de ser impressos. $\mathrm{O}$ plano era ambicioso, ${ }^{11}$ mas apenas três volumes vieram a ser de fato publicados. Entre eles, um que continha os dois primeiros livros da História do Brasil, de frei Vicente do Salvador, obra de 1627, dando início à importante história de Capistrano como editor de frei Vicente. Neste artigo, restringir-nos-emos aos trabalhos de anotação de Capistrano de Abreu, nas Informações e fragmentos históricos do padre José de Anchieta e nesta edição da História do Brasil, utili-

de Estudos Baianos; 1976, p. 139-140). Tomás Lino de Assunção (1844-1902), por sua vez, foi um engenheiro português, dedicado também às letras. Lino viveu no Rio de Janeiro, onde chegou a ter uma livraria. Sem muito sucesso, voltou à Europa, vivendo em Paris, e, depois, regressando a Portugal, onde seria nomeado secretário da Biblioteca Nacional de Lisboa e inspetor geral das Bibliotecas e Arquivos. Deve ter conhecido Capistrano, em sua estada no Brasil, por meio do núcleo da Gazeta de Noticias, onde Capistrano foi colaborador. Informações em ASSUMPÇÃO, Tomás Lino de (coord.). História geral dos jesuitas. Lisboa: Moraes Editores, 1982 (primeira edição c. 1901), e MINÉ, Elza. A geração de 1870 e o Brasil: alguns ângulos e percursos. In: <<http://www. fflch.usp.br/dlcv/posgraduacao/ecl/pdf/via09/Via\%209\%20cap15.pdf $\gg$ >. Acesso em: 22/09/2008; e MINÉ, Elza. Ferreira de Araújo, ponte entre Brasil e Portugal. Via Atlântica, n. 8, dez. 2005.

${ }^{10}$ Toda a correspondência com Lino de Assunção é importante nesse sentido, mas a carta de 12/03/1885 dá um exemplo do conhecimento que tinha Capistrano nessa área: o historiador cearense remeteu a Lino uma lista de documentos relativos ao século XVI existentes na Biblioteca Nacional, no Instituto Histórico e Geográfico Brasileiro e na biblioteca de sua majestade o imperador d. Pedro II (ABREU. Correspondência de Capistrano de Abreu, volume 3, op. cit., p. 306-310). Vale notar, nesse contexto, o domínio que Capistrano tinha dos instrumentos de pesquisa, como catálogos de bibliotecas e bibliografias, tal qual o Catalogo dos manuscritos da Bibliotheca Eborense, de autoria de Joaquim Heliodoro da Cunha Rivara, bibliotecário da Biblioteca de Évora, saído em 1850, e a Bibliotheca Americana Vetustissima, a description of works relating to America published between 1492 and 1551, de Henry Harrisse (Nova Iorque, 1866). Estudamos seu conhecimento e uso desses instrumentos em nossa dissertação de Mestrado: SANTOS, op. cit., em especial, p. 107-112.

${ }^{11}$ Em carta de 04/08/1886 a Lino de Assunção, Capistrano projeta dez volumes, no total, para a coleção. (ABREU. Correspondência, vol. 3, op. cit., p. 340); pouco mais tarde, em carta de 25/11/1886 ao barão do Rio Branco, imagina de seis a oito volumes (ABREU. Correspondência de Capistrano de Abreu, volume 1; op. cit., p. 104). 
zando apenas pontualmente o trabalho de Vale Cabral com as Cartas do padre Manoel da Nóbrega (estes os três volumes que de fato saíram). Não o fazemos por este último ser menos importante, ou menos significativo do ponto de vista do estudo da erudição histórica naquele período; muito pelo contrário, trata-se de trabalho notável, e Vale Cabral merece estudo. A restrição vem da relação deste texto com uma pesquisa mais ampla sobre Capistrano de Abreu que realizamos, de modo que nos é possível explorá-lo com mais profundidade.

\section{As anotações de Capistrano de Abreu}

Por que não dás a procedência dos documentos que publicas?

Félix Ferreira, sujeito aliás pouco fidedigno, contou-me que indo um dia visitar Melo Morais, encontrou-o queimando uns papéis: Estou queimando estes documentos, explicou-lhe o alagoano historiador, porque mais tarde, quando quiserem estudar História do Brasil hão de recorrer às minhas obras. Tu não és Melo Morais.

Varnhagen, pelo menos na Torre do Tombo, levou para casa alguns documentos e se esqueceu de restituí-los: não podia depois indicar a procedência. Tu não és Varnhagen.

Por que motivo, portanto, te insurges contra uma obrigação a que se sujeitam todos os historiadores, principalmente desde que, com os estudos arquivais, com a criação da crítica histórica, com a crítica das fontes, criada por Leopold von Ranke, na Alemanha, foi renovada a fisionomia da História? ${ }^{12}$

Essa interpelação é de Capistrano de Abreu a Guilherme Studart, em carta de 20/04/1904. Capistrano coloca como dever do historiador, naquele momento, a referência à procedência dos documentos que utiliza, localizando, em Leopold von Ranke, ponto inaugural do corpo de regras ao qual agora estariam sujeitos todos os historiadores. Ao fazê-lo, corrobora a versão que se tornaria lugar comum a respeito do sistema de referências enquanto fundamento da história dita moderna, ou científica; apresenta já, quase que contemporaneamente ao desenrolar desse processo, a versão que se consagraria: a de que é a partir de Leopold von Ranke que a história se torna científica, e a referência às fontes, concretizada principalmente via nota de rodapé, é parte fundamental deste feito, ao permitir a verificação e o confronto daquilo que diz o historiador no corpo de seu texto. Como afirma Anthony Grafton, "Todo garoto na escola sabe - ao menos todo aluno de ensino médio na Alemanha um dia soube - o que é história científica e quem a inventou. História científica baseia-se em fontes primárias, ao invés de fontes secundárias:

${ }^{12}$ ABREU. Correspondência, volume 1, op. cit., p.165-166, destaque nosso. 
Leopold von Ranke (...) foi seu primeiro praticante de destaque" ${ }^{13}$ Grafton mostra como as notas de rodapé eram uma dor de cabeça para o grande historiador alemão; ele as acrescentava, relutantemente, após concluir seus textos, o que lhe dava muitas vezes um trabalho ingrato de recuperar referências perdidas (nesse sentido, as notas surgem como "obrigação" do historiador no pior sentido da palavra). Mais do que isso, Grafton, estudando as origens da erudição, localiza, no final do século XVII e no século XVIII, o momento decisivo para a instituição da nota de rodapé como sistema de referências. ${ }^{14}$ Mas é importante ainda assim notar traços gerais e particulares desse processo que vão ser afirmados com tanta veemência no século XIX a ponto de fazer esse período tomar para si, na visão de contemporâneos e porvindouros, o lugar de instituidor destas práticas.

Um dos traços gerais é a afirmação, por meio da escrita de autores como Capistrano de Abreu, do texto historiográfico como uma "narrativa dupla", "que apresenta tanto os resultados finais, como explica o caminho necessário para se chegar a eles". ${ }^{15}$ Nas edições de documentos históricos, a dupla narrativa é formada pelo texto editado e as anotações críticas. Tal escrita trouxe à tona $\mathrm{o}$ caráter contingente do conhecimento histórico. ${ }^{16} \mathrm{O}$ século XIX, em particular, trouxe concepções e práticas que acabaram por reforçar esta tradição de erudição. Grafton resume o senso comum sobre a relação da nota de rodapé com o texto no XIX, para os historiadores, com um enunciado simples: "o texto convence, a nota prova". ${ }^{17}$ Mas o século XIX prossegue, e talvez expande, outro ramo da erudição, justamente o da edição e anotação de textos. No campo dos estudos históricos, em particular, cresce o trabalho e a importância da divulgação de fontes, inclusive por meio de edições críticas. Grafton destaca a contribuição de editores

${ }^{13}$ GRAFTON, Anthony. The footnote: a curious history. Cambridge, Mass.: Harvard University Press, 1998, p. 34 (tradução minha, como as demais citações de Grafton a seguir).

${ }^{14}$ GRAFTON, op. cit., p. 220-221.

${ }^{15}$ GRAFTON, op. cit., p. 200; Grafton vê em Pierre Bayle (1647-1706) um dos precursores desta escrita, em especial no seu Dictionnaire historique et critique (primeira edição, 1695-1697). Em Capistrano, esta dupla narrativa é muito bem analisada nos trabalhos de ARAÚJO, Ricardo Benzaquen de. Ronda noturna. Narrativa, crítica e verdade em Capistrano de Abreu. Estudos Históricos. Rio de Janeiro, número 1, 1988, e OLIVEIRA, op. cit. Sua escrita, ao revelar muitas vezes o processo de elaboração junto com o resultado final, funciona "quase como se Capistrano estivesse explicitando para o leitor uma etapa da pesquisa histórica que geralmente lhe é ocultada: a etapa da crítica da documentação", no dizer de Ricardo Benzaquen de Araújo (ARAÚJO, op. cit., p. 35). Certeau também fala no texto duplo, ou "folheado", em seu termo, formado pelo texto do historiador e as citações (CERTEAU, Michel de. A operação historiográfica. In: A escrita da história. Rio de Janeiro: Forense-Universitária, 1982, p. 101).

${ }^{16}$ GRAFTON, op. cit., p. 23.

${ }^{17}$ GRAFTON, op. cit., p. 15. Baseia-se no manual de Langlois e Seignobos para a asserção. 
ao estabelecimento da nota de rodapé moderna. ${ }^{18}$ Uma das fontes de Ranke (e do historismo como um todo) para a erudição seriam os editores e comentadores de textos antigos; um autor importante para historiadores desta tradição, no século XIX, foi Friedrich August Wolf, produtor de um trabalho crítico seminal sobre a obra de Homero, em inglês, os Prolegomena to Homer - o título e forma que dá a seu aparato crítico não passam despercebidos ao leitor de Capistrano de Abreu, conhecedor dos "Prolegômenos" à História do Brasil de frei Vicente do Salvador, edição de 1918. Desse modo, a tradição de anotação em edições de textos andou lado a lado com o estabelecimento de um corpo de regras, algumas implícitas, outras explícitas, da erudição histórica.

Nesse processo, Grafton parece recuperar, em seu raciocínio, o Ranke associado puramente a questões de método. Segundo Hans Schleier, mesmo sem ter escrito um tratado metodológico, e, na verdade, tendo publicado muito pouco sobre o assunto, o nome de Ranke ficou ligado ao método a tal ponto que seus discípulos, ou seguidores, eram chamados de Methodiker. ${ }^{19}$ Peter Novick considerou ter sido esta a recepção de Ranke nos EUA de grande importância para a constituição da história como disciplina acadêmica nesse país; ali, Ranke foi visto em função do método dos seminários e da crítica documental, quase que exclusivamente. ${ }^{20}$ Sérgio Buarque de Holanda discute as várias leituras feitas de Ranke, mostrando que o historiador alemão não praticava uma historiografia de erudição pura, ou uma ciência do único em sentido estrito (que, de mais a mais, seria uma impossibilidade, como mostra Sérgio Buarque) a orientar sua intensa pesquisa arquivística estavam algumas concepções filosóficas e historiográficas de base, e o recurso a seleções, generalizações e abstrações. Por exemplo, a ideia da "unidade fundamental dos povos românicos e germânicos na origem de toda história moderna", no estudo da história europeia. ${ }^{21}$ Nesse sentido, se tivermos de associar Capistrano a Ranke, será com o Ranke descrito por Sérgio Buarque. Pois, conforme pensava o autor de Visão do paraíso,

ele [Capistrano] sabia, no entanto, que esses documentos só falam verdadeiramente aos que ousam formular-lhes perguntas precisas e bem pensadas. Sabia, em outras palavras,

\footnotetext{
${ }^{18}$ Faz esse vínculo através de Leibniz, por exemplo (GRAFTON, op. cit., p. 210).

${ }^{19}$ IGGERS, Georg. G., POWELL, James M. (ed.). Leopold von Ranke and the shaping of the historical discipline. Syracuse, New York: Syracuse University Press, 1999, p. 111.

${ }^{20}$ NOVICK, Peter. That noble dream: the objectivity question and the American historical profession. Cambridge: Cambridge University, 1992.

${ }^{21}$ HOLANDA, Sérgio Buarque de (org.). Leopold von Ranke. São Paulo: Ática, 1979, p. 24. Mais à frente, Sérgio Buarque afirma que, sem esse "nexo de sentido" dado à história, "o estudioso do passado assumirá a posição de mero compilador de fatos, comportando-se passivamente diante deles" (p. 26).
} 
palavras de um grande mestre moderno - Marc Bloch -, que toda pesquisa histórica supõe, desde os passos iniciais, que o inquérito tenha uma direção definida. No princípio está o espírito. Nunca, em ciência alguma, a observação simplesmente passiva conduziu a resultados fecundos. ${ }^{22}$

As últimas palavras da citação Sérgio Buarque extraiu diretamente de Apologia da história; a prática de orientar as pesquisas e propor questões aos documentos a partir de problemas previamente definidos, porém, enxergava ser também um característico já do trabalho de Leopold von Ranke.

Se Capistrano procurou ser um praticante rigoroso destas regras de erudição e pesquisa com fontes, como as entendeu no trabalho de edição de textos? Para que serviam suas notas? Que relação possuíam com o texto editado?

Seu primeiro trabalho de edição anotada de um texto histórico são as Informações e fragmentos históricos do padre José de Anchieta, de 1886, primeiro número da Coleção Materiais e achegas para a história e geografia do Brasil. $\mathrm{O}$ volume em questão compõe-se de duas informações enviadas por Anchieta a seus superiores da Companhia de Jesus sobre a província do Brasil (província dos domínios da Companhia) e de um corpo de excertos denominados, por Capistrano, "Fragmentos históricos" - escritos de Anchieta sobre personalidades diversas de seu tempo, como o padre Manuel da Nóbrega. A primeira informação, "do Brasil e de suas capitanias", possui dezesseis notas de rodapé; a segunda, "da província do Brasil para nosso padre", possui oito notas. Os "fragmentos" não são anotados; o volume é completado por "Esclarecimentos", em número de três, referentes a elementos do texto que requereram, na visão do editor, explicação mais detida.

De modo a responder para que servem as notas, e que visão do texto elas denotam (da parte de seu editor e dos leitores que este tem em mente), estabelecemos uma tipologia. As notas das Informações, se bem as compreendemos, podem ser divididas em quatro tipos: retificação, complemento, indicação bibliográfica e discussão historiográfica.

Uma nota de retificação é, por exemplo, a nota cinco da primeira Informação:

${ }^{22}$ HOLANDA, Sérgio Buarque. O pensamento histórico no Brasil nos últimos 50 anos. EUGÊNIO, João Kennedy; MONTEIRO, Pedro Meira. Sérgio Buarque de Holanda: perspectivas. Campinas, SP: Editora da Unicamp; Rio de Janeiro, RJ: EdUerj, 2008, p. 602. Vale assinalar que as palavras de Marc Bloch, relembra Sérgio Buarque, das quais já teria um conhecimento intuitivo Capistrano de Abreu, ou seja, as três últimas frases da citação acima, são do capítulo "A observação histórica”, de Apologia da história. (BLOCH, Marc. Apologia da história, ou, O ofício do historiador. Rio de Janeiro: Jorge Zahar Ed., 2001, p. 79). 
Texto: $\quad \mathrm{Na}$ [capitania] de S. Vicente, que é de Martim Affonso de Souza.

Nota: Martim Affonso de Souza, primeiro donatario, não era então vivo [ou seja, capitania não era mais sua]. Desde 1572, succedera-lhe seu filho, Pedro Lopes de Souza (...). ${ }^{23}$

Os tipos que sugerimos não são rígidos; esta nota contém ainda uma indicação bibliográfica sobre a sucessão dos donatários da capitania de São Vicente (Pedro Taques, em edição da Revista do $I H G B$ ). De todo modo, sua função principal aqui parece ser corrigir a narrativa do padre Anchieta. A leitura do texto que faz o editor é de um banco de dados; fornece então ao leitor a informação correta. Onde não há correção, fica sugerido que o leitor pode tomar o relato como fiel aos fatos. ${ }^{24}$

Vejamos um exemplo de nota complementar, extraído também da primeira Informação (a primeira nota), que pormenoriza o que está no texto.

${ }^{23}$ Informações e fragmentos historicos do padre Joseph de Anchieta, S. J. (1584-1586). Rio de Janeiro: Imprensa Nacional, 1886, p. 1 (texto e nota de rodapé). Consultamos exemplar da biblioteca do Instituto de Estudos Brasileiros da Universidade de São Paulo, que tem as três edições da Coleção Materiais (Anchieta, Nóbrega e frei Vicente) encadernadas num mesmo volume.

${ }^{24}$ A expressão "banco de dados" é por nós usada no sentido das possibilidades de leitura dos documentos que julgamos ver Capistrano: os textos, se bem lidos (e aí surge uma condicionante que sabemos imprecisa) fornecem informações objetivas (quando, onde, quem, o que), provendo dados para campos de estudo interligados (história, geografia, etnografia) e para problemas para investigação já presentes na mente do editor. Capistrano julga, acreditamos, que o historiador deva levar em consideração quem escreveu o texto que lê; por que escreveu; quais os códigos que regem a escrita daquele tipo específico de texto, entre outros pontos (embora não explicite isso da forma como o fazemos aqui), mas coloca esses questionamentos de modo a eliminar obstáculos que dificultem a extração de informações do documento. Por conseguinte, "banco de dados" pode, talvez, ter o sentido de "arquivo", para Michel Foucault, em A arqueologia do saber: "a lei do que pode ser dito, o sistema que rege o aparecimento dos enunciados como acontecimentos singulares", na medida em que o documento baliza o que pode ser afirmado, como veremos Capistrano argumentar, mais à frente, em nosso estudo (FOUCAULT, Michel. A arqueologia do saber. Rio de Janeiro: Forense-Universitária, 1986, p. 149). Vale lembrar que o projeto filosófico de Foucault nessa obra, já delineado em Histoire de la folie, Naissance de la clinique e Les mots et les choses, pretende o combate ao sujeito antropológico e às continuidades postas, ou impostas, pelos historiadores à história (por isso os enunciados surgindo como "acontecimentos singulares"). Assinaladas essas especificidades, o pensamento foucaultiano sobre o arquivo é de extrema relevância numa análise da forma como os historiadores leem e pensam os documentos. 
Texto: $\quad$ Os primeiros portugueses que vieram ao Brasil foram Pedro Alvares Cabral com alguma gente em uma nau.

Nota: $\quad$ Aliás trese [a gente com que veio Cabral], o nome de cujos commandantes com pequenas divergencias trazem Castanhêda, Gaspar Correia, Barros e outros. ${ }^{25}$

Esta nota complementa a narrativa e indica as fontes onde buscar a informação ainda mais específica; também é um caso, portanto, de tipos misturados. Mas a nota acaba por quase poder ser colocada na sequência do texto, como um complemento seu. Aqui, a nosso ver, faz pleno sentido a noção de re-escrita da história em Capistrano de Abreu, apontada por Maria da Glória de Oliveira, e presente já na historiografia do IHGB. ${ }^{26}$

Prosseguindo, há o caso das notas que fornecem indicações bibliográficas para pesquisas sobre eventos narrados no texto. Por exemplo, a nota 7, novamente da primeira Informação:

Texto: $\quad$ No anno de 1564 chegou Estacio de Sá, sobrinho do governador Men de Sá, ao Rio de Janeiro, com a armada que trouxe de Portugal e muitos moradores do Brasil, assim Portuguezes como Indios christãos, e não indo bem fornecida do necessario para aquella empreza, se foi a S. Vicente, onde esteve apercebendo-se de mantimentos e do mais necessario. E fez canôas ligeiras em que no Janeiro seguinte com muita gente de S. Vicente, Portuguezes, Mamalucos e Indios, tornou ao Rio de Janeiro com os mais navios da armada, e no principio de Março.

Nota: $\quad$ Estes successos, a que esteve presente Anchieta [grifo nosso], vêm largamente narrados em uma carta sua escripta da Bahia aos 9 de Julho de 1565, publicada na Rev. do Inst., III, pg. 248/258 [grifo de Capistrano].

Por esta carta vê-se que a cidade do Rio de Janeiro começou a ser fundada a 1 de Março daquelle anno. ${ }^{27}$

A nota indica fonte mais completa sobre os "successos" narrados naquele trecho do texto - fonte, por sinal, já impressa; o leitor que quiser consultá-la tem mais facilidade do que se fosse um manuscrito. A fonte é uma carta do próprio

${ }^{25}$ Informações, op. cit., p. 1.

26 “Embora o conhecimento incorporado como uma 'tradição' historiográfica não possa ser revisado em sua totalidade, uma re-escritura da história implica que a crítica das fontes e a determinação dos fatos possam ser articulados novamente pela emergência de novos testemunhos ou, pelo menos, de um outro modo, pelo estabelecimento de novas questões, o que significa o reconhecimento da possibilidade da sua re-interpretação. É a partir desta perspectiva que o próprio saber histórico, em sua acepção científica moderna, assume um caráter tanto cumulativo quanto provisório, na medida em que, ao pressupor acréscimos, revisões e retificações, apresenta-se como processo infindável de acumulação/superação de 'verdades' parciais e relativas"; OLIVEIRA, op. cit., p. 65.

${ }^{27}$ Informações, op. cit., p. 7. 
Anchieta, e Capistrano destaca que o padre foi "testemunha presencial" 28 daqueles eventos, credenciando assim a fonte. $\mathrm{O}$ editor fornece ao leitor, desse modo, o aporte bibliográfico de domínio daqueles familiarizados com o estudo daqueles eventos específicos.

O outro tipo que propomos em nossa classificação foge desta perspectiva. As notas que apresentam discussões historiográficas tratariam justamente do "mundo dos especialistas" em estudos históricos, trazendo à tona questões não resolvidas, em que há confronto de opiniões e leituras divergentes de fontes. Em geral são as notas mais longas de Capistrano, e mais interessantes, ao apresentarem exemplos de sua escrita argumentativa, confrontando fontes e avaliando hipóteses. Um caso deste, em formato reduzido, nas Informações, é a nota 12 da primeira Informação:

Texto: Um dos moradores desta terra era um Joannes de Bolés, homem douto nas lettras latinas, gregas, hebraicas e mui lido na escriptura sagrada, mas grande herege. Este, com medo de Villegaignon que pretendia castigal-o por suas heresias, fugiu com alguns outros para S. Vicente nas canoas dos Tamoyos que iam lá á guerra com titulo de os ajudarem, e chegando a fortaleza da Bertioga se metteu nella com os seus e se ficou em S. Vicente. Alli começou logo a vomitar a peçonha de suas heresias, ao qual resistiu o padre Luiz da Grã e o fez mandar preso a Bahia e dahi foi mandado pelo bispo D. Pedro Leitão a Portugal e de Portugal á India e nunca mais appareceu.

Nota: $\quad$ Candido Mendes com razão considera este trecho prova cabal de que não é exacta a execução de J. Bollés por Anchieta, que os seus biographos lhe attribuem (Rev. do Inst., XLII, parte II, pg. 141/205.).

Que o João de Bollés de nossos chronistas era o Jean Cointa de Lery demonstraram-no o Dr. Ramiz Galvão (Rev. Brasil., vol. I, Rio, 1879, pg. 283) e Candido Mendes no trabalho citado. ${ }^{29}$

\footnotetext{
${ }^{28}$ Capistrano usa esta expressão em longo estudo que publicou no Jornal do Commercio em 1 e 16 de junho, e 1 de julho de 1899, reproduzido na Revista do Instituto Arqueológico e Geográfico Pernambucano em 1906, sobre a obra $O$ valeroso Lucideno e triunfo da liberdade, de frei Manuel do Salvador, obra da primeira metade do século XVII. Parte de sua importância como fonte estaria para os estudos da expulsão dos holandeses de Pernambuco, pois frei Manuel é, segundo Capistrano, "testemunha de alta valia" destes eventos, tendo sido "testemunha presencial dos seus primórdios" (ABREU, João Capistrano de. Ensaios e estudos: crítica e história. 1 1 $^{\text {a }}$ série, $2^{a}$ edição. Rio de Janeiro: Civilização Brasileira; Brasília: INL, 1975, p. 197). Utiliza a mesma expressão no prefácio à História topográfica e bélica da nova Colônia do Sacramento do Rio da Prata, de 1900, também para valorizar um testemunho (ABREU, João Capistrano de. Ensaios e estudos: crítica e história. $3^{\mathrm{a}}$ série, $2^{\mathrm{a}}$ edição. Rio de Janeiro: Civilização Brasileira; Brasília: INL, 1976, p. 49). Aspecto de sua concepção historiográfica destacado por ARAÚJO, op. cit., p. 38.

${ }^{29}$ Informações, op. cit., p. 11 (texto) e p. 11-12 (nota).
} 
São também notas bibliográficas (com referências precisas), mas a apresentar conclusões de historiadores sobre pontos que geraram polêmica. Nas anotações à História do Brasil de frei Vicente do Salvador, edição de 1887 da Coleção Materiais e achegas, encontram-se exemplos mais claros do caráter de discussão historiográfica que tomam algumas notas de Capistrano.

\subsection{Os esclarecimentos ao final do texto}

Ao final das Informações e dos Fragmentos (os últimos precedidos de uma explicação bibliográfica de Capistrano informando de onde foram extraídos estes excertos), Capistrano aduz "Esclarecimentos". O primeiro diz respeito a Francisco Pereira Coutinho, citado na p. 3 do volume, na primeira Informação. Dá a passagem de Coutinho, donatário da Bahia, pela capitania, seu refúgio em Porto Seguro e posterior morte nas mãos de índios. Transcreve dois documentos: um extrato de carta de Coutinho, segundo Capistrano presente "Em uma collecção de papeis velhos existentes na Bibliotheca Nacional"; e trecho do livro VII da Chancellaria de D. João III, "existente na Torre do Tombo". ${ }^{30}$ A primeira referência é notavelmente desleixada; a segunda deve ter sido obtida via Lino de Assunção. O segundo esclarecimento é sobre o "Clerigo nigromatico", a que faz menção Anchieta nas p. 5 e 6 do volume; Capistrano transcreve o que diz sobre ele frei Vicente do Salvador, passando pela menção que lhe fez Fernão Cardim - frei Vicente ainda não havia sido publicado, mas Capistrano sabia de sua iminente divulgação; a citação, nesse caso, é genérica, à obra e não a uma edição particular dela (livro III, cap. XV). O Cardim citado é o da obra que o próprio Capistrano editara em 1881.

O tratamento de Capistrano ao caso do padre "nigromatico", um clérigo que teria o poder de chamar os demônios do inferno, como relata frei Vicente, é significativo sob um aspecto: Capistrano não procede aqui diferente do que faz com os outros fatos relatados. Isto é, não procura desqualificar a parte fantástica da narrativa, nem dar-lhe alguma explicação "racional"; trata o caso como trata quaisquer dos demais fatos da narrativa. Tal posição é importante porque Capistrano está a editar, nos anos 1880, textos de jesuítas. Esta é uma época, tanto no Brasil como em Portugal, de disseminado antijesuitismo, associado à propaganda republicana nos dois países, que se expressava inclusive no descrédito dado às "superstições" dos discípulos de santo Inácio de Loyola. Tomás Lino de Assunção, que, como dissemos, auxiliava Capistrano, de Portugal,

${ }^{30}$ Informações, op. cit., p. 77-78. 
nas pesquisas que resultaram nas publicações da Coleção Materiais e achegas, é o autor de uma obra exemplar do antijesuitismo republicano em Portugal: a História geral dos jesuitas (c. 1901). Nela encontram-se exemplos desta outra atitude quanto a eventos sobrenaturais relatados pelos membros da ordem. Ao narrar o êxtase de uma semana que experimentou o fundador Inácio de Loyola, Lino aduz a seguinte nota:

Esta visão que dura oito dias não seria uma simples crise de catalepsia? Os pormenores precisos que fornecem as $<<$ testemunhas $>>$, além das suposições que os acompanham, parecem bastante característicos: rigidez absoluta dos membros, que persiste de um a outro sábado [tempo que durou o êxtase]; suspensão, pelo menos aparente, $<<$ de todas as faculdades de maneira que Inácio parecia como morto $>>$, a ponto que só deixam de o enterrar $<<$ quando percebem um bater que mal se sentia no coração $>>$; despertar $<<$ como de um sono $>>$ etc., etc... Uma tal crise era tanto mais verosímil [sic] quanto ele se achava enfraquecido pela doença, pelas penitências, jejuns, vigílias, que ele próprio, mais tarde, qualificará de coisas exageradíssimas, e cujos resultados não tardarão a manifestar-se sob a forma de perturbações mentais e nervosas. Tal, por exemplo, a tentação, ou talvez mesmo a tentativa de suicídio, relatada por Bartoli e outros historiadores, de que o curou o padre Pellaros $<<$ obrigando-o a comer a horas como toda a gente, sob pena de lhe recusar a absolvição $>>.31$

Este tipo de intervenção não ocorre nas edições de escritos jesuíticos (ou de outros religiosos) de Capistrano. Suas edições não contribuem para a valoração negativa do papel histórico das ordens religiosas na formação do Brasil, corrente em alguns círculos, em particular nos anos de crise do Império, quando saíram as edições da Materiais e achegas. No "debate cerrado sobre o papel construtivo ou corruptor do jesuitismo na formação brasileira", ${ }^{32}$ que se dá entre a geração de 1870, Capistrano, longe de ser católico, ou religioso, mas também sem ser um anticlerical fervoroso, faz edições que, se tanto, discretamente defendem o valor dos jesuítas na formação inicial do Brasil, nos primeiros anos da Colônia. Alfredo do Vale Cabral, no segundo volume publicado da Materiais, as Cartas do padre Manuel da Nóbrega, é bem mais explícito na valorização de seu herói:

O padre Manuel da Nobrega, um dos primeiros civilisadores desta terra, representa papel muito importante na sociedade brasileira e exerceu tanta influencia que seu nome será

${ }^{31}$ ASSUMPÇÃO. História geral dos jesuitas, op. cit., p. 23, nota 4. Sobre o antijesuitismo no Brasil, neste período, cf. ALONSO, Angela. Ideias em movimento: a geração 1870 na crise do Brasil-Império. São Paulo: Paz e Terra, 2002, p. 173-174.

32 ALONSO, op. cit., p. 173. Sobre a relação de Capistrano com o catolicismo, há o estudo de Virgínia A. Castro Buarque sobre Capistrano e sua filha Honorina, tornada freira carmelita: Escrita singular: Capistrano de Abreu e madre Maria José. Fortaleza: Museu do Ceará, Secretaria da Cultura, 2003. 
sempre lembrado. Sua fama era geral em todo o Brasil e tambem aos sertões do Paraguay chegou a grande nomeada dos seus trabalhos, das suas virtudes. (...) Em todos os logares que percorreu tão bons serviços prestou que ligou seu nome á historia geral do paiz. Seu merecimento é bastante conhecido.

Todo o mundo sabe o que fez em prol da terra que se lhe rasgava aos olhos; e o movimento que imprimiu no Brasil entre os dois povos, o civilisado e o inculto, o invasor e o indígena, foi de certo superior ao de Anchieta, ainda que este fallasse correntemente a lingua dos Indios, o que não alcançou Nobrega, provavelmente pelo defeito natural que tinha. Mas, apesar de gago, com a sua palavra soube conquistar Portuguezes e Brasis. Tinha o coração generoso, era verdadeiro amigo da Humanidade. Desbastou a terra, ganhou-lhe amor; não temia o encontro de milhares de Indios, fallando-lhes com toda a energia e desassombro por meio de interpretes $(. . .)^{33}$

Capistrano, conquanto nunca antijesuíta, não demonstra a mesma admiração por Anchieta e sua obra "civilizatória" que Vale Cabral expõe ao falar de Nóbrega. Na introdução, Capistrano valoriza os textos que apresenta enquanto fontes, e sua biografia do autor é fria e objetiva. Valorizava os jesuítas (Cardim, Anchieta, Nóbrega e outros) como bons observadores da realidade que viviam; sua opinião sobre a obra da ordem na colonização, em geral positiva, exporia em outros espaços, como os Capítulos de história colonial (1907).

Nos Capítulos, Capistrano adotará postura favorável aos jesuítas, por exemplo frente aos bandeirantes. Após o relato do ataque a uma redução jesuítica, que culminou na queima da igreja onde se refugiava o povo da redução, como modo de fazê-lo sair e massacrá-lo em sua fuga, Capistrano pergunta: “Compensará tais horrores a consideração de que por favor dos bandeirantes pertencem agora ao Brasil as terras devastadas?" ${ }^{34}$ No relato de novos conflitos, Capistrano afirma: "Defendidos por seu caminho inexpugnável, os paulistas expulsaram os jesuítas, que só voltaram anos depois, à força de negociações e concessões. Implantou-se, portanto, o sistema seguido nas terras espanholas de encomendas ou administração dos índios; algumas encomendas por testamento couberam finalmente à Companhia de Jesus. Imagina-se mal neste figurino oportunista a consciência

\footnotetext{
${ }^{33}$ NÓBREGA, Manoel da. Cartas do Brasil, 1549-1560. Belo Horizonte: Itatiaia; São Paulo: Editora da Universidade de São Paulo, 1988, p. 16-17. Esta edição baseia-se na re-edição das cartas feita por Afrânio Peixoto que reproduz o aparato crítico da edição de Vale Cabral, de 1886 - que também consultamos no original, encadernada no mesmo volume das outras duas publicadas da Materiais - Anchieta (1886) e frei Vicente (1887) - em exemplar da biblioteca do IEB-USP.

${ }^{34}$ ABREU, João Capistrano de. Capítulos de história colonial. 1500-1800. $7^{\mathrm{a}}$ ed. rev. anotada e prefaciada por José Honório Rodrigues. Belo Horizonte: Itatiaia; São Paulo: Publifolha, 2000 (Coleção Grandes Nomes do Pensamento Brasileiro), p. 131.
} 
heróica de Manuel da Nóbrega". ${ }^{35}$ Vemo-lo aí lembrar Nóbrega com reverência semelhante à que adotara Vale Cabral na Coleção Materiais.

Daniel Mesquita Pereira destaca a diferença na ação dos jesuítas e dos bandeirantes, para Capistrano: os primeiros, com os aldeamentos e as missões, eram conquistadores do território, isto é, fixavam-se ali e constituíam núcleos de povoamento. Os bandeirantes, embora tenham desbravado o território, apenas ocasionalmente fixavam-se no sertão (quando então passavam a conquistadores, e, assim, cumpriam papel importante); no mais, retornavam a São Paulo, em geral deixando rastro de destruição, de despovoamento. ${ }^{36}$ Sendo a ocupação do território o principal problema historiográfico da história do Brasil, para Capistrano, a ação dos jesuítas fora mais importante, para a formação do país, que a dos bandeirantes. Ciro Flávio Bandeira de Melo aponta uma diferença na visão sobre os jesuítas da geração de Capistrano para a geração anterior, de Varnhagen, através do estudo do manual didático de João Ribeiro, a História do Brasil para o ensino superior (1900). O valor das missões e aldeamentos jesuítas na ocupação do território e na formação de centros de povoamento, a defesa dos índios e mesmo o trabalho pedagógico dos inacianos faziam com que a presença da Companhia, malgrado erros que tenha cometido, tenha sido mais benéfica que prejudicial na história do Brasil, para Ribeiro. Melo contrapõe o manual de João Ribeiro ao de Joaquim Manuel de Macedo, Lições de história do Brasil (dois volumes, 1861-63), que segue a linha da História geral do Brasil de Varnhagen (primeira edição, 185457), e que foi adotado no Colégio Pedro II, onde Macedo lecionava história do Brasil. Nas Lições, como na obra do visconde de Porto Seguro, os jesuítas são vistos como influência maléfica no processo de colonização. Isto porque sua ação comumente os colocava em conflito com o Estado português e, na interpretação de Varnhagen e Macedo, escrevendo no Império (e de um ponto de vista imperial), o Brasil era obra do Estado monárquico português, a concretização de seu projeto civilizatório. Para João Ribeiro, na República (e de um ponto de vista republicano), o Brasil se fez, como coloca Ciro Bandeira de Melo, apesar do Estado português, e não através dele. Ribeiro destacará a ação particular de uma sociedade civil na formação do país, muitas vezes em contradição ou conflito aberto com a ação do colonizador estatal. ${ }^{37}$ Esta visão em muito se aproxima da

\footnotetext{
${ }^{35}$ Ibidem, p. 132.

${ }^{36}$ PEREIRA, Daniel Mesquita. Descobrimentos de Capistrano. A história do Brasil "a grandes traços e largas malhas”. Tese de Doutorado, Programa de Pós-Graduação em História Social da Cultura do Departamento de História da PUC-Rio. Rio de Janeiro, 2002, p. 99-103.

${ }^{37}$ MELO, Ciro Flávio de Castro Bandeira de. Senhores da história e do esquecimento: a construção do Brasil em dois manuais didáticos de história na segunda metade do século XIX. Belo Horizonte:
} 
de Capistrano de Abreu, configurando um dado curioso: no Brasil, diferente de em Portugal, de Lino de Assunção, a geração do advento da República, embora, em geral, tenha se afastado da religião, na vaga dos influxos cientificistas e racionalistas de fins do século XIX, talvez tenha sido menos antijesuíta que a geração que viveu a consolidação do Império brasileiro, de resto mais valorizadora do papel do catolicismo na formação do país.

Mas um aspecto fundamental que transparece da edição de documentos jesuíticos é não apenas o valor dado pelos autores à obra da ordem, denotando que a edição de fontes era orientada por ideias mais ou menos claras sobre a história do Brasil, que lhes guiavam nas pesquisas, como também a percepção da necessidade de melhor conhecer a história dos jesuítas no Brasil, como uma lacuna em nossa historiografia. E isso também retornará nos Capítulos, em mais um momento, agora o da expulsão da ordem dos domínios portugueses, sob Pombal, em que Capistrano se posiciona favoravelmente aos discípulos de santo Inácio:

Uma história dos jesuítas é obra urgente; enquanto não a possuirmos será presunçoso quem quiser escrever a do Brasil [o que relativiza a importância da própria obra que está escrevendo].

Nas suas diferentes casas devem ter ficado numerosos e importantes documentos, que o desleixo ou propósito aniquilou; salvaram-se apenas os títulos de suas propriedades. A julgar por algumas publicações e documentos fornecidos a Eduardo Prado e a Studart os arquivos europeus devem ser ricos.

Enquanto não se fizer a luz sobre tão obscuros assuntos, um juízo definitivo a respeito da famosa ordem pecará pela base. Em todo caso pouca, muito pouca inteligência revelam os ataques dirigidos contra ela. Instintivamente a simpatia volta-se para os discípulos e companheiros de Nóbrega, Anchieta, Cardim, Vieira, Andreoni, os educadores da mocidade, os fundadores da linguística americana. ${ }^{38}$

Em passagens como essa, une-se em Capistrano a história - processo histórico - e a história - relato desse processo -, ou, história e historiografia. O relato e a interpretação dos acontecimentos é intercalado pelo questionamento das condições presentes de conhecimento desses acontecimentos. Presentes porque Capistrano mantém a perspectiva de um continuado processo de revelação e disponibilização de fontes, do qual ele mesmo era parte. Nesse sentido, a Coleção Materiais orienta-se pelas preocupações historiográficas de seus editores, pelos problemas que estes (e sua época) colocavam à história do Brasil; e trazia

Argumentum, 2008, p. 121-129.

${ }^{38}$ ABREU. Capítulos de história colonial, op. cit., p. 193. 
o propósito de diminuir os "pecados de base" na historiografia brasileira, isto é, aumentar as condições de conhecimento de nossa história.

\subsection{A escrita argumentativa no comentário aos textos históricos}

O terceiro esclarecimento no volume de Anchieta é o mais extenso. O trecho de Anchieta a que se dedica o esclarecimento ${ }^{39}$ relata a vinda dos primeiros religiosos ao Brasil, que seriam da ordem de S. Francisco e teriam chegado a Porto Seguro pouco depois do povoamento dessa capitania. Um dos frades afogou-se em um rio, que por este motivo ficou conhecido como "rio do Frade". Os demais foram mortos por índios, que então adotaram (segundo a narrativa de Anchieta) uma emboscada para atacar os portugueses que viessem depois: vestiram-se com as roupas dos religiosos e fingiram-se de franciscanos, matando os portugueses que então se aproximassem.

Capistrano analisa a narrativa, em uma nota que cobre três páginas, ${ }^{40}$ do ponto de vista da veracidade da anedota sobre a emboscada; da tentativa de estabelecer quando vieram estas missões franciscanas; e onde tudo isto se passou, isto é, em que pontos, pela nomenclatura geográfica atual (isto é, de 1886), poderiam ser localizados estes eventos. Procede analisando versões de "historiadores" e estudando "documentos contemporaneos", em seus termos. Entre os primeiros, inclui frei Antônio da Piedade, autor de uma Crônica da Arrabida, e frei Antônio de Santa Maria Jaboatão (1695-1779), autor do Orbe seráfico brasílico, junto com Varnhagen, na História geral - os primeiros são também chamados de "chronistas" por Capistrano, cronistas que foram da ordem de São Francisco. Os documentos de época de que se vale são uma carta escrita da Bahia, em 1551, pelo padre Francisco Pires, dando como referência de procedência tratar-se de um manuscrito da Biblioteca Nacional, o Esmeraldo de situ orbis (1506) de Duarte Pacheco, códice da Biblioteca de Évora, ainda inédito, indicando que obtivera cópia por intermédio de Lino de Assunção, e o Tratado descritivo de Gabriel Soares, já publicado. Os documentos lhe servem essencialmente para averiguar a data dos eventos, a partir de quem os narrou (isto é, de quando se tornaram conhecidos), "e para evitar anacronismos", principalmente quanto aos termos e localizações geográficas. Da cópia do Esmeraldo, por exemplo, Capistrano extraiu uma lista das latitudes de uma série de pontos geográficos, que transcreve no final do esclarecimento; esta lista dá as latitudes "da época", não as corrigidas pela

\footnotetext{
39 Informações, op. cit., p. 12.

40 Informações, op. cit., p. 79-81.
} 
moderna cartografia. O conhecimento do contexto histórico permite-lhe fazer asserções por analogia e lógica. Por exemplo: alguns autores insistiam que os franciscanos haviam sido mandados para Porto Seguro. Capistrano explica: "Este argumento perde, porém, a força si nos lembrarmos que nos primeiros tempos era usual designar toda uma terra apenas por uma localidade mais conhecida, como succedeu, por exemplo, no Amazonas, onde a expressão Cabo do Norte significava toda a Guyana brasileira. Porto Seguro quer dizer portanto o mesmo que Brasil". ${ }^{41}$

Capistrano pesa os relatos dos "historiadores" com as fontes contemporâneas. Os cronistas franciscanos chamam os frades de Arrabidos; "Ora, em mappas antigos apparece o nome de Santa Maria d'Arrabida, um pouco ao Norte do cabo de Santo Agostinho. Portanto é ahi que se deve localisar seu primitivo estabelecimento". ${ }^{42}$ Conferindo com as latitudes do Esmeraldo, descobre que esta localidade era marcada em $5^{\circ}$, em 1506.

Ora [novamente, a linguagem da argumentação, ou mesmo da conversa] si compararmos esta latitude com a da bahia da Traição, não como a trazem as cartas actuaes, depois de tantas determinações astronomicas, mas com os documentos contemporaneos [grifo nosso], encontramos na doação de Pero Lopes que a bahia da Traição é arrumada em $6^{\circ}$, isto em 1534, depois de muitas explorações, entre as quaes a de Diogo Leite em 1531. A posição é, pois, muito próxima entre os dois pontos.

Sobre a designação do lugar vir da emboscada dos índios, Capistrano afirma apenas se saber a este respeito o que está no Tratado de Gabriel Soares, mas este, "em vez de estar em desaccôrdo com o facto, pelo contrario, combina perfeitamente com elle" - para a verificação do que Capistrano transcreve trecho da obra. Colocou, portanto, sua hipótese à prova da fonte e obteve uma "combinação perfeita" entre ambas. Capistrano conclui que o episódio do rio do Frade é separado daquele da emboscada. ${ }^{43}$

As anotações aos textos editados, ao envolverem a verificação dos fatos relatados, para o leitor, continham muitos exemplos da escrita argumentativa de Capistrano, permitindo-nos ver como utilizava as fontes, principalmente para o confronto com as versões de cronistas e historiadores. Nelas, demonstrava domínio desta bibliografia, toda indicada nas notas.

${ }^{41}$ Informações, op. cit., p. 80.

${ }^{42}$ Informações, op. cit., p. 80-81.

${ }^{43}$ Informações, op. cit., p. 80. 


\subsection{A bibliografia das notas às Informações}

A publicação mais citada nas dezesseis notas da primeira Informação de Anchieta é a Revista do Instituto Histórico e Geográfico Brasileiro, com quatro citações, compreendendo uma monografia (Cândido Mendes) e fontes impressas (duas cartas do próprio Anchieta, Pedro Taques e Gabriel Soares de Sousa). Em seguida, aparece a monografia Brésil français, de Gaffarel (que Capistrano também usa na tese de 1883 sobre o Descobrimento, que lhe valeu o ingresso no Colégio Pedro II; aliás, dada a proximidade de época tratada e temas, a bibliografia da primeira Informação é quase a mesma da tese), com três citações consecutivas. ${ }^{44}$ Nas oito notas da segunda Informação, Capistrano cita três vezes a Revista do $I H G B$, uma vez um manuscrito do Instituto, e três vezes Varnhagen (sendo que, entre as citações da RIHGB, uma é novamente a Gabriel Soares, publicado ali por Varnhagen, que assim lidera entre os autores citados, também aparecendo nos esclarecimentos). Dentre as menções à RIHGB, cita Pedro Taques e Gabriel Soares, saídos ali, e uma monografia de Joaquim Norberto de Sousa e Silva. Varnhagen é mencionado pela História geral e pelas edições de Gabriel Soares e da Narrativa epistolar de Fernão Cardim. A bibliografia desta segunda Informação é também muito próxima da usada na tese de 1883, qual seja: a monografia de Wieser (sobre a história da descoberta do estreito de Magalhães), as coleções de textos históricos de Navarrete e Purchas, Ramusio (obra sobre as navegações do início do século XVI), e genealogistas como Taques e Borges da Fonseca (este a partir da Revista do Instituto Arqueológico e Geográfico Pernambucano), para informações biográficas e, no caso de Borges, para a história regional de Pernambuco; além do Catálogo da Biblioteca de Évora.

Evidentemente que, malgrado as críticas que Capistrano tinha ao IHGB, o conhecimento do arquivo e da revista da instituição não deixavam de ser, para ele, domínios indispensáveis aos estudiosos da história do Brasil. Ainda assim, podemos aventar a hipótese de que Capistrano já trabalha muito fora destes domínios. ${ }^{45} \mathrm{O}$ IHGB é talvez menos mencionado do que seria de se esperar - e, no campo das monografias, aparecem as exceções que Capistrano via no Instituto,

\footnotetext{
${ }^{44}$ Notas 9, 10 e 11, que tratam do trecho da Informação a respeito da presença francesa no Brasil, naquele período.

45 Alguns artigos de Capistrano na imprensa expõem duras críticas ao Instituto, como os de 17 de abril de 1880 (Uma grande ideia) e 2 de setembro de 1881, publicados na Gazeta de Notícias, e reproduzidos em ABREU. Ensaios e estudos: crítica e história. $4^{\text {a }}$ série, op. cit., p. 89-92 e p. 280-283, respectivamente. GONTIJO, op. cit., capítulos 1 e 6; e AMED, 2006, op. cit., p. 174177 fornecem estudos sobre a relação entre Capistrano e o Instituto.
} 
como Cândido Mendes de Almeida e Joaquim Norberto. Mesmo os documentos publicados na RIHGB não escapariam de críticas de Capistrano, como já vimos. Por outro lado, e isto vai ficar claro nas notas à edição de frei Vicente pela Coleção Materiais, Varnhagen é praticamente um guia para o estudo da história colonial, seja pelos documentos que trouxe à luz (malgrado as críticas que suas edições também poderiam receber de Capistrano), ${ }^{46}$ seja pela sua narrativa, de conhecimento inescapável para quem estudasse os primeiros séculos da colonização portuguesa na América (mesmo que, às vezes, tivesse de ser refutada, ou retificada, não podia ser, todavia, ignorada). A postura de Capistrano em relação a Varnhagen nessas anotações, nesse sentido, não parece diferir muito da que adotou no "Necrológio" de 1878 e nos artigos de 1882, em que, malgrado as insuficiências da obra de Varnhagen e a necessidade de renovação em alguns pontos, fica também clara a condição inescapável da mesma para o estudioso de história do Brasil e, mesmo, o caráter precursor de Varnhagen em instâncias como a própria edição de documentos - discutiremos mais adiante um pouco mais da posição de Capistrano em relação ao visconde de Porto Seguro.

\section{A edição de 1887 de frei Vicente do Salvador}

Apesar da fama dos "Prolegômenos" da edição de 1918, a anotação da História do Brasil, edição de 1887, é também um grande trabalho desta linha realizado por Capistrano, tanto em tamanho como em profundidade; esta edição da História, porém, não foi integral. São 106 notas de rodapé aos dois primeiros livros (dos cinco) da História $;^{47} 104$ notas numeradas, uma com numeração repetida (existem duas notas 82 ), e uma que "Por descuido deixou de sahir" no livro I, ${ }^{48}$ incluída no final; além de cinco notas mais extensas ao final do livro I, e quatro ao término do livro II, perfazendo um total de 115 notas.

\footnotetext{
${ }^{46}$ Nessa época em que trabalhava nas edições da Coleção Materiais, por exemplo, Capistrano escreveu a Lino de Assunção, em 2 de junho de 1886, pedindo que Lino providenciasse o cotejo do texto da Narrativa epistolar, de Fernão Cardim, editada por Varnhagen, com exemplar da Biblioteca de Évora, pois "Consta-me (...) que a Narrativa epistolar editada por Varnhagen é muito incorreta" (ABREU. Correspondência de Capistrano de Abreu, volume 3, op. cit., p. 335).

${ }^{47}$ Os três outros livros deixaram de sair nesta edição por dois motivos principais: o trabalho de elaboração das notas revelou-se muito custoso e demorado e Capistrano e Vale Cabral não queriam adiar ainda mais o lançamento da obra, interessados inclusive em fazê-lo num dia 20 de dezembro, data em que frei Vicente concluiu a História, para marcá-la enquanto efeméride na historiografia brasileira; além disso, os três outros livros tinham muitas partes faltantes e Capistrano alimentava firmemente a esperança de encontrar um exemplar inteiro, para, aí sim, dar a obra completa (esperança que nunca perdeu, aliás, e que, até hoje, ninguém conseguiu concretizar).

${ }^{48}$ SALVADOR, frei Vicente do. História do Brasil. Rio de Janeiro: Imprensa Nacional, 1887, p. 100.
} 
A classificação que fizemos das notas das Informações de Anchieta também observamos nestas anotações; ou seja, elas podem ser divididas basicamente em: 1) notas de retificação a alguma informação do texto; 2) notas de complemento ao texto; 3) notas que fornecem indicações bibliográficas sobre nomes ou eventos mencionados por frei Vicente; e 4) notas de discussão historiográfica - ressaltando que não há, para Capistrano, uma hierarquia entre os tipos. Por outro lado, se, em Anchieta, Capistrano reservou "esclarecimentos" para o final do texto, na História encontramos algumas notas de rodapé com essa função. A nota 12, por exemplo: ${ }^{49}$ frei Vicente menciona um "bispo de Tucuman" e a nota de rodapé esclarece que trata-se de Francisco Victoria, e ainda fornece uma pequena biografia sua, dando a obra de onde a extraiu..$^{50}$

Destarte, a leitura que o editor faz do texto, e, por conseguinte, aquela que imaginava que fariam seus leitores, não difere muito da que teve em mente na edição de Anchieta: a História é lida enquanto banco de dados para estudos de história, geografia e etnografia, principalmente. $\mathrm{O}$ editor entende seu dever informar ao leitor onde a narrativa factual está incorreta e onde ela pode ser completada, além de indicar fontes e monografias que trazem novas informações ou análises daquilo que está contido no texto de frei Vicente, permitindo ao leitor se atualizar e/ou se aprofundar nesses temas.

As notas desta edição contêm, porém, alguns pontos que merecem estudo. $\mathrm{O}$ primeiro que gostaríamos de apontar refere-se a uma nota em que o trabalho a que se propôs o anotador não pôde ser realizado; no insucesso, seu método e aquilo que procurava para as anotações acabam por se revelar com mais clareza. No primeiro parágrafo do capítulo XII do livro II, frei Vicente fala de um Francisco de Braga; a nota 94 diz: "De Francisco de Braga não tenho encontrado menção em outro autor ou em documento algum contemporaneo. Pelo texto, sua administração deve ter sido depois de Novembro de 1532, acabando antes de 1539, pois a atilada de Duarte Coelho é anterior á morte de Pero Lopes". ${ }^{51}$ Neste caso, vemos como procedia Capistrano: ao se deparar com um nome, procurava outro documento contemporâneo ou narrativa em que aparecesse mencionado; tentava extrair o máximo de informações biográficas e históricas a seu respeito, e dava as referências dos textos onde encontrasse as menções - o que não foi possível com Francisco de Braga. Na ausência de outras referências, só tinha o texto que

\footnotetext{
${ }^{49}$ A numeração das notas da História é contínua, isto é, as notas não são zeradas ao final do livro I; assim, a primeira nota do livro II é a nota 35 .

${ }^{50}$ SALVADOR, frei Vicente do, op. cit., 1887, p. 9.

${ }^{51}$ SALVADOR, frei Vicente do, op. cit., 1887, p. 93.
} 
anotava como fonte e, então, procurava extrair o máximo dele - nestas situações, fazia inferências a partir do texto. É um tipo de procedimento que vemos colocado com clareza por Vale Cabral, no outro número publicado da Coleção Materiais, as Cartas de Nóbrega. A segunda carta não traz o dia em que foi escrita, "mas do contexto vê-se que é de segunda feira 15 de Abril" ${ }^{52}$ - um dos muitos casos em que Vale Cabral extrai "do contexto", isto é, das informações contidas na narrativa do texto, um dado que não vem expresso positivamente.

A falta de documentos que atestassem "positivamente" alguma data ou informação levava Capistrano não apenas a procurar inferências do contexto, como a valer-se, em muitos casos, de conjecturas. Existem algumas notas conjecturais na edição de 1887 da História do Brasil, como a nota 84: frei Vicente, no primeiro parágrafo do nono capítulo do livro II, menciona um Vasco Fernandes de Lucena; o anotador deveria então identificar tal pessoa. A nota diz:

Os documentos contemporaneos fallam mais de uma vez de um Vasco Fernandes, que ocupou o logar de almoxarife, e feitor régio de Pernambuco até 1554. Embora não tenha o sobrenome de Lucena, é bem possivel que fosse este [grifo nosso]. Em Março de 1548, escrevia Duarte Coelho que havia treze annos que Vasco Fernandes estava com elle em Pernambuco (Porto Seguro, Hist., p. 175). ${ }^{53}$

Vale Cabral, na edição das Cartas de Nóbrega, traz colocações significativas a respeito do procedimento das anotações da Coleção Materiais, quanto a esse aspecto:

Anotei as presentes cartas tanto quanto me foi possivel fazel-o; uns factos ficaram mais ou menos assentados, outros devem ser estudados de novo até sua completa elucidação. Si tivessemos todas as cartas dos Jesuitas do XVI seculo, de certo ahi encontrariamos elementos para a solução das duvidas que a cada passo se affloram á tela da discussão. Por isso ás vezes soccorri-me de conjecturas fundadas nas proprias cartas dos Padres que possuimos e em outros documentos contemporaneos que pude consultar. ${ }^{54}$

Cabral expressa, na explicação de suas anotações, seu trabalho de apuração dos fatos, vinculado intrinsecamente à disponibilidade de documentos contemporâneos por onde se fiar; sua ausência leva ao trabalho por conjectura, a partir das fontes existentes, e à postergação de um exame mais rigoroso destes fatos

\footnotetext{
52 NÓBREGA, op. cit., p. 14.

${ }^{53}$ SALVADOR, frei Vicente do, op. cit., 1887, p. 83. Entre outros exemplos de notas que apresentam conjecturas na História, identificamos as notas 19 e 45, além das de discussão historiográfica.

${ }^{54}$ NÓBREGA, op. cit., p. 13.
} 
para quando maior documentação estiver disponível. Um número maior de documentos poderia servir para o estabelecimento de uma série - mais confiável que alguns poucos documentos; mas para muitos fatos e nomes, o problema é que não existia qualquer menção nas fontes existentes (nesse sentido, se houvessem uma ou duas extraordinariamente completas e fidedignas, o problema se resolveria).$^{55}$ O editor é aquele que, em suma, "tudo interroga (...), tudo confirma, para alcançar a realidade e conseguir maior clareza", como disse Capistrano ao elogiar o editor do Diário de Pero Lopes de Sousa, Eugênio de Castro, na edição de 1927 da Série Eduardo Prado, com a qual também colaboraria. ${ }^{56}$

\subsection{A discussão de polêmicas historiográficas nas notas}

A edição de 1887 da História do Brasil é também notável por algumas notas de rodapé (além das maiores, ao final dos livros I e II) em que Capistrano discute pontos controversos entre os historiadores. É o caso da primeira nota, que vem após frei Vicente afirmar a casualidade do Descobrimento do Brasil. Capistrano remete à discussão entre Joaquim Norberto (que a contesta) e Machado de Oliveira e Gonçalves Dias (que a afirmam), travada na RIHGB, volumes XV e XVIII. Embora não se posicione aqui, a questão foi tratada por Capistrano pouco tempo antes, em 1883, na tese sobre o Descobrimento do Brasil que lhe valeu o ingresso no corpo de professores do Colégio Pedro II. Na tese, Capistrano contesta Joaquim Norberto e dá razão, em certo sentido, a Gonçalves Dias. Porém, reorienta a questão toda, ao focar na viagem de Vasco da Gama e nos ensinamentos que este teria passado a Pedro Álvares Cabral (que, de posse dessas informações, teria uma orientação implícita de buscar novas terras a ocidente no caminho para as Índias); de modo que, por fim, aponta para a não casualidade do descobrimento do Brasil, mas em bases diferentes das de Joaquim Norberto. ${ }^{57}$ Vale se questionar por que Capistrano não optou por fazer aqui também uma nota extensa, colocando suas posições sobre o assunto; isto é, por que a casualidade do Descobrimento não foi considerada, aqui, um tópico para discussão mais ampla.

\footnotetext{
${ }^{55}$ A anotação por conjectura e aquela a partir do contexto dado pelo próprio texto aparecem num estudo de caso de Anthony Grafton, que examina a obra de um corretor e editor do início da era moderna na Europa: Correctores corruptores? Notes on the social history of editing. In: MOST, Glenn W. (ed.). Editing texts: Texte edieren. Göttingen: Vandenhoeck und Ruprecht, 1998, p. 54-76, em especial p. 74-76.

${ }^{56}$ ABREU, João Capistrano de. Ensaios e estudos: crítica e história. $2^{\mathrm{a}}$ série, $2^{\mathrm{a}}$ edição. Rio de Janeiro: Civilização Brasileira; Brasília: INL, 1976, p. 245.

57 ABREU, João Capistrano de. O descobrimento do Brasil. Rio de Janeiro: Civilização Brasileira; Brasília: INL, 1976, p. 35-38.
} 
Na terceira nota, Capistrano trata da diferença de opiniões entre Varnhagen e Beaurepaire Rohan a respeito de Porto Seguro, neste caso dando a discussão como vencida por este último.

Algumas notas deste tipo, entretanto, assumem proporções pouco usuais para notas de rodapé. A primeira assim é a nota 33 (que ocupa boa parte das páginas 36 e 37), ainda entre as anotações do livro I, em que frei Vicente fala de um privilégio concedido pelo papa aos bispos de possessões portuguesas para casarem índios no mesmo dia em que os batizavam. Cândido Mendes de Almeida julgou inautêntica a bula que teria concedido o privilégio. Capistrano o refuta, rebatendo seus argumentos, mas encerrando de fato a discussão com a transcrição de trecho de documento contemporâneo. É nas anotações ao livro II, porém, que as notas de rodapé deste gênero tornam-se textos em que Capistrano refuta ou apoia argumentos, discute fontes e avalia hipóteses. (Vale dizer que o livro I da História é mais descritivo, tratando do território e das populações indígenas; o segundo é mais histórico - se contamos três notas de discussão historiográfica no primeiro livro, no segundo achamos oito).

A primeira nota ao livro II já é nessa linha. Frei Vicente começa este livro falando da armada que o rei de Portugal mandara ao Brasil, comandada por Gonçalo Coelho. A nota, que se estende por duas páginas (ocupando a maior parte de ambas), é sobre essa armada. Capistrano versa sobre contradições e dúvidas a respeito da expedição. A primeira concerne ao tempo que ficou Gonçalo Coelho no Brasil; a segunda, se fundou ou não feitoria no Rio de Janeiro, como concluiu Varnhagen ("por sugestões de J[oaquim]. C[aetano]. da Silva", segundo Capistrano) interpretando legenda de cartas da época ("mas, segundo Wieser, é pouco segura paleographicamente esta interpretação"); a terceira dúvida é a respeito de quantas naus teriam se perdido da armada e o que ocorreu com elas. Termina a nota com informação biográfica sobre o que sucedeu a Gonçalo Coelho após a dita expedição.

Esta nota é muito importante enquanto exemplar da escrita argumentativa de Capistrano. Nela, cita Damião de Góes (Crônica de d. Manuel), Gabriel Soares (Tratado descritivo) e as Décadas de João de Barros; Varnhagen (Nouvelles recherches sur la derniers voyages du navigateur florentin), Franz Wieser (embora não especifique, deve ser a monografia Magalhães-Strasse und Austral-continent uf den Globen des Johannes Schoener, Innsbruck, 1881, que vinha utilizando) e Navarrete, além da carta de um navegador da época. Quanto a Varnhagen e 
Wieser, discute suas interpretações e hipóteses. Os cronistas e fontes servem-lhe de prova ou fonte de informação. ${ }^{58}$

Nestas notas, Capistrano procura, onde possível, recorrer às fontes primárias para resolver as controvérsias. Na nota 42 , por exemplo, em que discute as interpretações para a extensão da capitania doada a Pero Lopes de Sousa, Capistrano refuta especialmente a conclusão de Lopes Machado, pois "não resiste ao estudo dos documentos". ${ }^{59}$ Vemo-lo por em prática, assim, essencialmente, sua defesa do conhecimento das fontes e das monografias. Na mesma linha, se procurou chamar a atenção, também via edição de documentos, para pontos importantes da história do Brasil que julgava pouco estudados, não considerou de menor valor à precisão quanto a datas e fatos, de modo a se chegar a uma narrativa factual sólida de nossa história. Disso é exemplo a nota 85:

Texto: Vendo Duarte Coelho que a terra estava quieta, e os moradores contentes, determinou ir-se a Portugal com seus filhos, deixando o governo da capitania a seu cunhado Hyeronimo de Albuquerque em companhia da irmã.

Nota: Duarte Coelho esteve seguramente em Portugal duas vezes, - a primeira antes de 1547, quando fez contracto com alguns negociantes para a fundação de engenhos, e a segunda depois de 1552, talvez em meiado de 1553. (Em companhia de Thomé de Sousa? E' natural [outra forma de afirmação por lógica] que o Governador, que ainda não visitara as capitanias do Norte, fizesse-o na sua partida para Europa, na intenção de dar informações completas a D. João III.) Segundo Jaboatão (Orbe Seraphico, I, p. 143), Duarte Coelho falleceu em Olinda a 7 de Agosto de 1554; mas isto não pode ser exacto nem quanto ao dia, porque muito bem observa Porto Seguro que já a 10 de Maio era passada a carta de confirmação a favor de seu filho (Hist., p. 271); nem quanto ao local, porque, como se vê adiante [em frei Vicente] foi em Lisboa". ${ }^{60}$

Ainda quanto à anotação da narrativa do texto, há na História do Brasil dois novos tipos de nota: um que o anotador confirma o que diz frei Vicente (apenas um caso, a nota 52 - dissemos que, onde não há confirmação, está implícito que a narrativa editada está correta) e cinco casos em que faz um confronto entre as fontes (notas 54, 67, a segunda nota 82, 87 e 97). A confirmação refere-se à extensão de capitania doada; a narrativa do frei é atestada por dois documentos,

\footnotetext{
${ }^{58}$ Uma nota deste tipo aparece em publicação de acesso muito mais fácil que esta edição de 1887 da História do Brasil. Capistrano reproduziu a nota 37 no já citado prefácio à História topográfica e bélica da nova Colonia do Sacramento do Rio da Prata que, por sua vez, se encontra reproduzido na terceira série dos Ensaios e estudos, op. cit., p. 66-69.

${ }^{59}$ SALVADOR, frei Vicente do, op. cit., 1887, p. 59-60.

${ }^{60}$ SALVADOR, frei Vicente do, op. cit., 1887, p. 84.
} 
a carta de doação e o foral, publicados na $R I H G B$. No caso do confronto entre relatos, em três casos, as notas 54, 67 e 97, Capistrano não resolve as contradições; apenas dá as diferentes versões. Nos outros dois, propõe conjecturas para explicar de onde viriam as discrepâncias. Destarte, na segunda nota 82 (lembrando que a chamamos assim porque, na edição, saíram duas notas com a numeração 82) confronta a narrativa de frei Vicente com o relato de Hans Staden: "Hans Stade [sic] esteve em Pernambuco em 1548, de fins de Janeiro a fins de Abril, e conta alguns factos semelhantes aos narrados por nosso autor". Capistrano os resume, apontando a seguir que,

Apezar das semelhanças entre estas narrativas, ha pelo menos dois pontos de divergência a assignalar: o cerco a que Hans Stade assistiu durou so um mez, e ninguém morreu dos Christãos.

Que Affonso Gonçalves não morreu desta feita sabe-se ainda pela sua carta de 3 de Maio [a cronologia é o decisiva aqui; Staden esteve em Pernambuco de janeiro a abril, como dissera Capistrano] (...). E', pois, provavel [grifo nosso] que Hans Stade assistiu apenas a parte do drama e que este primeiro assedio não fosse mais que o começo de outro muito mais prolongado e mortífero. ${ }^{61}$

Desse modo, procura fornecer ao leitor a narrativa mais exata possivel.

\subsection{As notas ao final dos livros I e II}

As notas ao final do livro I são sobre o pau-brasil: a primeira refere-se a espécies de madeira pau-brasil, sua origem geográfica, a origem de seus nomes e o processo de extração da tinta. A segunda nota transcreve texto de Joaquim Caetano da Silva, na Revista do IHGB (tomo XXIX, $2^{\mathrm{a}}$ parte, p. 18-24) em que este investiga a etimologia das denominações do pau-brasil; o estilo de escrita, argumentativa e conjectural, em muito lembra a que vimos Capistrano adotar em muitos momentos. A terceira refuta "o eminente conhecedor da historia do descobrimento do Brazil [sic, embora Capistrano fizesse questão do Brasil com s], F. A. de Varnhagen", a respeito de quando o nome Brasil começou a ser empregado para a América portuguesa; Capistrano dá exemplos de uso anterior a 1511, data defendida por Varnhagen. ${ }^{62}$ A quarta nota dá preços e cotações do pau-brasil no início do século XVI e seu uso como forma de pagamento, citando o corpo cronológico da Torre do Tombo e a História geral de Varnhagen. Aúltima

${ }^{61}$ SALVADOR, frei Vicente do, op. cit., 1887, p. 84.

${ }^{62}$ SALVADOR, frei Vicente do, op. cit., 1887, p. 48. 
nota transcreve um regimento do rei de Portugal sobre a extração e comércio do pau-brasil, a partir de Nabuco Araújo, Collècção Chronologico-Systematica da Legislação de Fazenda.

Este conjunto de notas é interessante porque, entendendo que seu dever como editor e anotador da História do Brasil envolvia retificar ou complementar a narrativa onde necessário, Capistrano, de certa forma, procurava estabelecer uma narrativa histórica precisa, como dissemos. ${ }^{63}$ Estas notas, a nosso ver, são indícios de seu trabalho de escrita de uma história do Brasil nos moldes como a entendia. Um capítulo sobre o pau-brasil está de forma embrionária nestas anotações ao final do livro I; aliás, parecem mesmo anotações suas, com as fontes e monografias de que se valeria para escrever o capítulo - os fragmentos da pesquisa antes do trabalho final da escrita, como se revelasse ali o trabalho de pesquisa e fichamento do historiador, normalmente vedado ao leitor da obra pronta. ${ }^{64}$ Por isso, sua advertência inicial, de que ali colocava "algumas notas sobre o páo que deu nome ao Brasil. Em occasião mais conveniente serão talvez completadas". ${ }^{65}$

Algo semelhante aparece nas notas ao final do livro II. São cinco: a primeira é nota que deveria ter saído no rodapé do texto; a segunda e a quinta são complementares a pontos do texto: a segunda transcreve trecho de Fernando de Soledade, Historia seraphica (Lisboa, 1705), tratando da primeira armada que veio ao Brasil, e a quinta transcreve excerto da História geral de Varnhagen sobre as questões de limites entre as capitanias de São Vicente e Santo Amaro.

A terceira e a quarta são relativas a donatários. A terceira, a mais extensa do volume, indo da p. 100 até a p. 109, dá uma lista da sequência dos donatários de cada capitania, que Capistrano elenca na medida em que pôde apurar. É importante aqui a descendência e a ascendência dos donatários, para esclarecer a linha sucessória em cada capitania. Por isso, Capistrano imaginava que seu trabalho pudesse ser completado por "Quem quer que for versado em nobiliarchia portugueza".

Porém, em poucos momentos, Capistrano cita diretamente genealogistas: uma vez Pedro Taques (p. 102), duas vezes Braz da Costa Rubim (p. 103 e 104) e uma vez Sousa, Historia genealógica da Casa Real (p. 107), embora mencione outras obras deste gênero ao final das notas, quando dá as fontes em que se baseou para esta terceira nota (p. 115). Possuía desconfianças quanto às genealogias existentes, como revela em muitos momentos da sua correspondência e, em colocação que pode ser tomada como exemplar, na nota 77 desta edição, em que escreve:

\footnotetext{
${ }^{63}$ Lembrando aqui, novamente, a noção de reescrita colocada por OLIVEIRA, op. cit.

${ }^{64}$ Como apontado por ARAÚJO, op. cit., p. 35.

${ }^{65}$ SALVADOR, frei Vicente do, op. cit., 1887, p. 44.
} 
Outra cousa: Jaboatão (...) dá a descendencia de Caramurú; mas entre seus genros não enumera genro algum hespanhol. E' mais uma prova da pouca consciencia com que foram feitos os nossos trabalhos genealogicos, dos quaes apenas se salvam parcialmente os de Taques e talvez os de Borges da Fonseca. ${ }^{66}$

A crítica de Capistrano aos genealogistas vinha de seu confronto com o que o historiador encontrava nas fontes primárias; neste apanhado dos donatários, Capistrano segue principalmente as cartas de doação, confirmação e alvarás produzidos no decorrer do processo de transmissão das terras. Em um caso, confronta um genealogista, e dá como que o ethos de seu proceder: "Esta lista de donatarios, deduzo-a de carta de confirmação de Antonio Luis da Camara Coutinho. Não concorda com a lista de Braz da Costa Rubim (...). E' provavel que esta lista esteja mais certa; mas eu não posso dar sinão o que se contem nos documentos que compulsei". ${ }^{67}$ Este ethos o impele a informar onde não obteve a informação necessária, por exemplo: “(...) Passou então a capitania [de Pernambuco] ao marquez de Louriçal, ultimo donatario, que a vendeu á Corôa, ignoro quando e por quanto. Das capitanias de João de Barros, Fernando Alves de Andrada, Ayres da Cunha e Luis de Mello da Silva, ignoro si houve successão ou transacção" ${ }^{68}$ Todavia, já o vimos, sua noção do uso do documento não se prendia à informação positiva que pudesse extrair; onde não a encontrasse, se os documentos e os conhecimentos existentes permitissem, poderia fazer conjecturas, como: "Muito pouco conhecida é a historia desta [capitania, a do Recôncavo baiano], da qual, a falar verdade, só se conhecem com certeza os dois primeiros e o ultimo donatario. O seguinte é o que se apurou de mais provavel". ${ }^{69}$ Aqui, aponta os pontos sabidos "com certeza" e, por conseguinte, os ignorados, como fizera antes, mas arrisca uma conjectura para os desconhecidos.

Capistrano assume como proposta, desse modo, uma narrativa calcada nas fontes, com a qual complementar ou retificar textos de outros autores, ou suprir uma lacuna (no caso da nota sobre os donatários, pois afirma faltar uma lista sequencial dos donatários por capitania). Ao final destas notas ao livro II, Capistrano coloca as fontes em que se baseou, e também as obras históricas e

\footnotetext{
${ }^{66}$ SALVADOR, frei Vicente do, op. cit., 1887, p. 76-77. Aliás, as genealogias vinham sofrendo crítica já há alguns anos, pelo menos; em artigo de 5/10/1881, na Gazeta de Notícias, Capistrano remete a crítica de Cândido Mendes de Almeida: "como afirmava Cândido Mendes, (...) as genealogias de Taques, Borges da Fonseca e outros contêm muitas alegações fantásticas, e nem sempre são dignas de crédito" (ABREU. Ensaios e estudos: crítica e história, 4ª série, op. cit., p. 295).

${ }^{67}$ SALVADOR, frei Vicente do, op. cit., 1887, p. 104, grifo nosso.

${ }^{68}$ SALVADOR, frei Vicente do, op. cit., 1887, p. 109, grifos nossos.

${ }^{69}$ SALVADOR, frei Vicente do, op. cit., 1887, p. 107, grifos nossos.
} 
genealógicas. Entre as primeiras, está a História geral de Varnhagen. Quando a utiliza, na nota em que lista os donatários, Capistrano parece usar informações da obra que não conseguiu conferir nos documentos, nem para confirmar, nem para rejeitar, como: "A este comprou D. José a capitania, ignoro em que data; mas, segundo Porto Seguro, pela pensão de $640 \$ 000 " .{ }^{70}$ E Varnhagen é, com efeito, a principal referência bibliográfica usada nas notas ao livro II de frei Vicente; sua narrativa constitui-se quase como um guia para os estudos dos primeiros séculos da colonização portuguesa na América.

Na quarta nota, Capistrano divulga dois documentos - p. 109-113 - apontando dois dos critérios que poderiam levar um documento à publicidade: "Por muito curiosos e pouco conhecidos, junto os dous documentos relativos a donatarios: os autos das arrematações da capitania dos Ilhéos e o auto de posse da capitania de Porto Seguro". ${ }^{71}$ Tratara na extensa nota anterior da transmissão de posse das capitanias, mas, ao dar estes documentos, não os apresenta como representativos dos processos de transmissão e, sim, como "muito curiosos e pouco conhecidos". A curiosidade, acreditamos, viria principalmente do registro da oralidade do leilão que contém passagens como "Dou-lhe uma, dou-lhe duas e uma mais pequenina e outra mais pequenina. Em praça vendo, em praça arremato, affronta faço que mais não acho que dezesete mil cruzados por esta capitania. Há quem mais me dê, mais quem mais me diga?"; provavelmente a divertir o leitor, além de fornecer-lhe fonte para estudo.

\subsection{A bibliografia das notas da História do Brasil (1887)}

A bibliografia das notas ao livro I é consideravelmente dispersa. Parte descritiva da obra de frei Vicente, talvez se enquadrasse, na divisão das ciências de fins do século XIX, como História natural, contendo a descrição do território e dos índios, principalmente (embora comece com a descoberta do Brasil). As notas apontam para cronistas (João de Barros e Gaspar Correia, por exemplo), obras que continham fontes, como Navarrete (indicado como fonte para o Tratado de Tordesilhas), a carta de Pero Vaz de Caminha, entre outros documentos de época e monografias, notadamente sobre as viagens do período e a etnografia brasílica. A obra mais citada é a Revista do IHGB e o autor mais citado é Varnhagen,

70 SALVADOR, frei Vicente do, op. cit., 1887, p. 108.

${ }^{71}$ SALVADOR, frei Vicente do, op. cit., 1887, p. 109. Capistrano esclarece, na bibliografia que dá ao final das notas, que o auto de posse extraiu de Lemos Mesa, Doação da capitania de Porto Seguro, e os leilões da carta de doação ou da carta de confirmação (não especifica qual) de d. Luiz Innocencio de Castro. 
com cinco menções cada. Da RIHGB, Capistrano aponta as polêmicas entre Joaquim Norberto, Machado de Oliveira e Gonçalves Dias, e entre Varnhagen e Beaurepaire Rohan, além de Cândido Mendes, Joaquim Caetano e Gandavo, reproduzido na publicação. Segue, assim, apontando os documentos importantes ali transcritos e as monografias mais relevantes, em sua visão.

Nas notas ao livro II, porém, Varnhagen reina absoluto. É citado 33 vezes nas 75 notas (contando aquelas ao final do livro, o que também fizemos na contagem do livro I). A História geral (primeira ou segunda edição, o que Capistrano diferencia) é mobilizada 23 vezes; uma vez as Nouvelles recherches sur la derniers voyages du navigateur florentin; e por nove vezes Capistrano cita edições de documentos de Varnhagen: o Tratado de Gabriel Soares (seis vezes), a Narrativa epistolar de Fernão Cardim (uma vez), e o Diário de Pero Lopes de Sousa (duas vezes). O Diário e o Tratado foram editados por Porto Seguro na Revista do $I H G B$, embora, ao que parece, também devam ter saído avulsos; incluindo-as como citações a esta publicação, temos 21 menções à $R I H G B$, ainda assim consideravelmente aquém do historiador paulista.

Nestas notas, que versam basicamente sobre os séculos XVI e XVII de nossa história, percebe-se a grande importância atribuída por Capistrano a Varnhagen, exposta no "Necrológio" (1878) e em artigos de 1882. ${ }^{72}$ Ainda que deva ser refutada em alguns pontos, a História geral destaca-se, como dissemos acima, quase como um guia daquele período, época pouco estudada na visão de Capistrano. E os documentos que Varnhagen desencavou dos arquivos, motivo de grandes elogios de Capistrano nos textos citados, têm aqui sua importância demonstrada. É como se, na prática, no estudo da história do Brasil, Capistrano revelasse o quão incontornável era a obra de Varnhagen, mesmo com as críticas e ressalvas que nunca deixou de fazer. Dentre estas, muitas vinham da diferença entre ambos no trato com documentos, que transparece em um trabalho de anotação como este de Capistrano e que motivaria algumas das retificações à obra de Varnhagen que Capistrano julgava necessárias. Quase trinta anos depois de editar os volumes que viemos analisando, Capistrano escreveu a João Lúcio de Azevedo, em carta de 9 de março de 1918: "Varnhagen era incapaz de inventar documentos, mas lia-os tão mal! Muitas vezes concluo de modo diferente dele; outras noto que ele deixa o substancial para apegar-se ao acessório". ${ }^{73} \mathrm{Na}$

\footnotetext{
${ }_{72}$ Ambos reproduzidos na $1^{\mathrm{a}}$ série dos Ensaios e estudos, op. cit., p. 81-91 (Necrológio), e p. 131147 (artigos de 1882).

73 ABREU, João Capistrano de. Correspondência de Capistrano de Abreu, volume 2. Edição organizada e prefaciada por José Honório Rodrigues. $2^{\mathrm{a}}$ edição. Rio de Janeiro: Civilização Brasileira;
} 
edição de 1918 da História do Brasil de frei Vicente do Salvador, Capistrano mencionará documentos que Varnhagen parece ter utilizado na História geral, mas sem explicitar a referência e a procedência. ${ }^{74}$ Mais grave, porém, deve ter sido a "desoladora convicção" que teve Capistrano durante estes anos em que editava a Coleção Materiais e que confidenciaria, em carta de 30/03/1887, ao barão do Rio Branco: "o nosso ilustre historiador [Varnhagen] roubava papéis". ${ }^{75}$ Por extraviar papéis dos arquivos, segundo Capistrano, Varnhagen não poderia depois indicá-los em seus textos.

A noção de objetividade das fontes que Capistrano mostra na Coleção Materiais é matizada (ou ao menos seria, nas décadas seguintes, até a carta para João Lúcio) pela importância da interpretação adequada das fontes: é possível lê-las mal, não entendê-las, não extrair delas as informações corretas. Simultaneamente, e isto já é claro na Coleção Materiais, está a noção de um conhecimento produzido e legitimado coletivamente; daí a necessidade de indicar a procedência das fontes, para permitir que outros estudiosos vejam em que se baseou o autor que leem (e possam, assim, tirar suas próprias conclusões).

\section{Conclusão}

O que as anotações revelam sobre a forma como o editor lia os textos? O que elas podem dizer da expectativa que tinha em relação ao uso do texto publicado que fariam os leitores? Podemos dizer que procurou direcionar a leitura? $\mathrm{Ou}$, reformulando a questão: se o trabalho do editor configura, em casos como este, um inevitável direcionamento da leitura, em que sentido Capistrano procurou guiá-la?

Acreditamos que uma leitura dos textos como banco de dados, fontes de informação para variados estudos (história, geografia, etnografia, folclore etc.) transparece nas notas. $\mathrm{O}$ título da coleção já explicita este propósito, de fornecer materiais e subsídios para o trabalho em história e geografia. Nesse sentido, se há um aspecto memorialista neste caso de edição de documentos históricos, que poderia ser o de estabelecer uma "memória coletiva" dos primeiros tempos da colônia, ele apareceria sujeito a um projeto historiográfico: as correções e retificações procuram informar a história conhecida daqueles tempos, mas as indicações bibliográficas e os pontos ainda obscuros, ou em aberto, indicam o trabalho a ser feito. Trabalho este que os editores esperam seja assentado nas fontes primárias,

Brasília: INL, 1977, p. 84.

${ }^{74}$ SALVADOR, frei Vicente do. História do Brasil. São Paulo: Edições Melhoramentos, 1975, p. 135,141 e 312 .

75 ABREU. Correspondência de Capistrano de Abreu, volume 1, op. cit., p. 111. 
lidas, criticadas e citadas com rigor. O rigor e o método do editor podem ser lidos, assim, como lições de rigor e método ao leitor.

A tipologia que tentamos estabelecer para as notas de Capistrano pode servir para o vislumbre das tarefas que via à frente dos autores de estudos históricos de seu tempo: retificar as narrativas conhecidas da história do Brasil, elaborar a narrativa dos pontos desconhecidos ou ainda pouco estudados dessa história, mantendo-se, ao mesmo tempo, atualizado na bibliografia e atento à questão da disponibilização das fontes. A obrigação da citação das fontes e das monografias lidas pode ser indício da tentativa de fazer prevalecer uma ética entre pares (como parece ser o caso na admoestação de Capistrano a Studart), bem como de uma concepção coletiva de produção de conhecimento: não mais o historiador isolado em seu gabinete, cercado de fontes que procura esconder dos demais, tentando escrever sozinho toda a obra histórica (como por vezes parece sugerir a caracterização de Capistrano de autores da geração que lhe antecede, como Melo Morais e Varnhagen), mas o autor cônscio de suas limitações e da grandeza da história a ser abarcada pelo conhecimento, ciente da necessidade de sua escrita ser empreendida por vários estudiosos, compartilhando suas conclusões e descobertas.

Pensando o conjunto da obra de Capistrano, chama a atenção, evidentemente, a ausência do rigor demonstrado nessas anotações, presente também em outros momentos de sua produção, nos Capítulos de história colonial (1907). Explicar os motivos dessa ausência nos escapa, aqui ${ }^{76}$ podemos vislumbrar, contudo, o caráter da obra que Capistrano imaginava ser necessária para superar a História geral de Varnhagen, através do trato minucioso da narrativa factual, das notas de rodapé e indicações bibliográficas.

${ }^{76}$ PEREIRA, op. cit., estuda justamente a elaboração dos Capitulos, sobre o que há também a introdução de José Honório Rodrigues presente em várias edições da obra, como a que utilizamos aqui. AMED, 2006, op. cit., retoma a questão da história do Brasil que Capistrano não chegou a escrever (a que poderia, enfim, tomar o posto da História geral de Varnhagen), e que era muito esperada por seus contemporâneos, tema de estudo muito comum a seus primeiros biógrafos e comentadores. 


\section{Referências bibliográficas}

ABREU, João Capistrano de. Ensaios e estudos: crítica e história. $1^{\mathrm{a}}$. série. $2^{\mathrm{a}}$. edição. Rio de Janeiro: Civilização Brasileira; Brasília: INL, 1975.

ABREU, João Capistrano de. Ensaios e estudos: crítica e história. $2^{\mathrm{a}}$ série. $2^{\mathrm{a}}$ edição. Rio de Janeiro: Civilização Brasileira; Brasília: INL, 1976.

ABREU, João Capistrano de. Ensaios e estudos: crítica e história. $3^{\mathrm{a}}$ série. $2^{\mathrm{a}}$ edição. Rio de Janeiro: Civilização Brasileira; Brasília: INL, 1976.

ABREU, João Capistrano de. Ensaios e estudos: crítica e história. $4^{\text {a }}$ série. Rio de Janeiro: Civilização Brasileira; Brasília: INL, 1976.

ABREU, João Capistrano de. O descobrimento do Brasil. Rio de Janeiro: Civilização Brasileira; Brasília: INL, 1976.

ABREU, João Capistrano de. Correspondência de Capistrano de Abreu, volume 1. Edição organizada e prefaciada por José Honório Rodrigues. 2 ed. Rio de Janeiro: Civilização Brasileira; Brasília: INL, 1977.

ABREU, João Capistrano de. Correspondência de Capistrano de Abreu, volume 2. Edição organizada e prefaciada por José Honório Rodrigues. $2^{\text {a }}$ edição. Rio de Janeiro: Civilização Brasileira; Brasília: INL, 1977.

ABREU, João Capistrano de. Correspondência de Capistrano de Abreu, volume 3. Edição organizada e prefaciada por José Honório Rodrigues. $2^{\text {a }}$ edição. Rio de Janeiro: Civilização Brasileira; Brasília: INL, 1977.

ABREU, João Capistrano de. Capítulos de história colonial. 1500-1800. $7^{\mathrm{a}}$ ed. rev. anotada e prefaciada por José Honório Rodrigues. Belo Horizonte: Itatiaia; São Paulo: Publifolha, 2000 (Coleção Grandes Nomes do Pensamento Brasileiro).

ALONSO, Angela. Ideias em movimento: a geração 1870 na crise do Brasil-Império. São Paulo: Paz e Terra, 2002.

AMED, Fernando José. As cartas de Capistrano de Abreu: sociabilidade e vida literária na belle époque carioca. São Paulo: Alameda, 2006.

AMED, Fernando José. Atravessar o oceano para verificar uma vírgula: Francisco Adolfo de Varnhagen (1816-1878) lido por João Capistrano de Abreu (18531927). Tese de Doutorado, Programa de Pós-Graduação em História Social do Departamento de História da FFLCH-USP, São Paulo, 2007.

Anais da Biblioteca Nacional, volume 73, 1954.

ARAÚJO, Ricardo Benzaquen de. Ronda noturna. Narrativa, crítica e verdade em Capistrano de Abreu. Estudos Históricos. Rio de Janeiro, n. 1, 1988.

ASSUMPÇÃO, Tomás Lino de (coord.). História geral dos jesuítas. Lisboa: Moraes Editores, 1982 (primeira edição $c$. 1901).

BLOCH, Marc. Apologia da história, ou, O ofício do historiador. Rio de Janeiro: Jorge Zahar Ed., 2001.

CERTEAU, Michel de. A operação historiográfica. In: A escrita da história. Rio de Janeiro: Forense-Universitária, 1982, p. 65-114. 
FOUCAULT,Michel.Aarqueologiadosaber .Riode Janeiro:Forense-Universitária, 1986.

Gazeta Literária. Ano I, n 3, $1^{\circ}$ de novembro de 1883.

Gazeta Literária. Ano I, $\mathrm{n}^{\circ} 5,1^{\circ}$ de dezembro de 1883.

Gazeta Literária. Ano I (sic), n² 20, 24 de novembro de 1884.

GONTIJO, Rebeca, $O$ velho vaqueano: Capistrano de Abreu, da historiografia ao historiador. Tese de Doutorado, UFF, Niterói, 2006.

GRAFTON, Anthony. The footnote: a curious history. Cambridge, Mass.: Harvard University Press, 1998.

GRAFTON, Anthony. Correctores corruptores? Notes on the social history of editing. In: MOST, Glenn W. (ed.). Editing texts: Texte edieren. Göttingen: Vandenhoeck und Ruprecht, 1998.

HOLANDA, Sérgio Buarque de (org.). Leopold von Ranke. São Paulo: Ática, 1979.

HOLANDA, Sérgio Buarque de. O pensamento histórico no Brasil nos últimos 50 anos. EUGÊNIO, João Kennedy; MONTEIRO, Pedro Meira. Sérgio Buarque de Holanda: perspectivas. Campinas, SP: Editora da Unicamp; Rio de Janeiro, RJ: Ed. Uerj, 2008.

IGGERS, Georg. G., POWELL, James M. (ed.). Leopold von Ranke and the shaping of the historical discipline. Syracuse, New York: Syracuse University Press, 1999.

Informações e fragmentos historicos do padre Joseph de Anchieta, S. J. (1584-1586). Rio de Janeiro: Imprensa Nacional, 1886.

MOST, Glenn W. (ed.). Editing texts: Texte edieren. Göttingen: Vandenhoeck und Ruprecht, 1998.

NÓBREGA, Manoel da. Cartas do Brasil, 1549-1560. Belo Horizonte: Itatiaia; São Paulo: Editora da Universidade de São Paulo, 1988.

NOVICK, Peter. That noble dream: the objectivity question and the American historical profession. Cambridge: Cambridge University, 1992.

PEREIRA, Daniel Mesquita. Descobrimentos de Capistrano. A história do Brasil “a grandes traços e largas malhas”. Tese de Doutorado, Programa de Pós-Graduação em História Social da Cultura do Departamento de História da PUC/RJ. Rio de Janeiro, 2002.

OLIVEIRA, Maria da Glória de. Crítica, método e escrita da história em João Capistrano de Abreu (1853-1927). Dissertação de Mestrado, Programa de Pós-Graduação em História da Universidade Federal do Rio Grande do Sul. Porto Alegre, 2006.

Revista do Instituto Histórico e Geográfico Brasileiro, tomo LVII, part. $1^{\mathrm{a}}$., $1^{\mathrm{o}}$. e $2^{\mathrm{o}}$. trimestres de 1894.

Revista do Instituto Histórico e Geográfico Brasileiro, tomo XXIX, 2a parte, 1866.

Revista Mensalda Seção da Sociedade de Geografia de Lisboano Brasil, set.-out.de 1885.

Revista Mensal da Seção da Sociedade de Geografia de Lisboa no Brasil, 2ª série, $\mathrm{n}^{\circ} 4$, primeiro trimestre de 1886 . 
SALVADOR, frei Vicente do. História do Brasil. Rio de Janeiro: Imprensa Nacional, 1887.

SALVADOR, frei Vicente do. História do Brasil. Rio de Janeiro: Tip. Leuzinger \& Filhos, 1889.

SALVADOR, frei Vicente do. História do Brasil. São Paulo: Edições Melhoramentos, 1975.

SANTOS, Pedro Afonso Cristovão dos. História erudita e popular: edição de documentos históricos na obra de Capistrano de Abreu. Dissertação de Mestrado, FFLCH-USP, São Paulo, 2009.

Recebido: 19/01/2010 - Aprovado: 24/07/2010 